\title{
Two tales of contraction: gender wage gap in Georgia before and after the 2008 crisis
}

\author{
Tamar Khitarishvili
}

Correspondence: khitaris@levy.org Levy Economics Institute of Bard College, 75 Blithewood Ave. Annandale on Hudson, NY 12504, USA

\begin{abstract}
This paper examines the contraction in the gender wage gap in Georgia between 2004 and 2011. Behind the continuous decline at the mean lies a change in the shape of the gender wage gap across the wage distribution before and after the 2008 crisis. Before the crisis, the growth in state sector wages and the expansion of construction and transport industries contributed to these developments. After the crisis, it was the contraction of male-dominated industries and potentially the female added-worker effect. In the analysis, we employ the decomposition approaches proposed in Firpo et al. (Decomposing wage distributions using influence function projections, 2007) and Ñopo (The Rev of Econ and Stat 90:290-299, 2008).
\end{abstract}

JEL Classification: J16, J31, P2

Keywords: Gender wage gap, Decomposition methods, Wage distribution, Transition economies, Georgia

\section{Introduction}

This paper examines the evolution of the gender wage gap across the wage distribution in Georgia between 2004 and 2011. During the period that followed the Rose Revolution of 2003, the Georgian government implemented a broad set of reforms that entailed the restructuring of the public sector, privatization of state-owned enterprises, and sharp reductions in the costs of conducting business (Papava 2012). This period also coincided with the recession, which came on the heels of the 2008 financial crisis and the August War with Russia. Between 2004 and 2007, the Georgian economy expanded at an average annual growth rate of $9.3 \%$, in part buoyed by the growth of the state sector. In 2008, the growth slowed down to $2.3 \%$, and the Georgian economy entered a recession in 2009. Although output growth resumed after 2009, in 2011, the economy was still recovering from the impact of the crisis.

These developments were bound to alter the gender balance in labor markets in Georgia. However, the direction of the changes in the gender wage gap at the mean and across the wage distribution during this period is ambiguous. Empirical evidence documenting the evolution of the gap across wage distribution in the transition region reflects this ambiguity. ${ }^{1}$ Ganguli and Terrell (2005) find that the gender wage gap narrowed in Ukraine between 1986 and 2003 and that this decline was primarily caused by the reduction in the gender wage gap at the bottom of the distribution. Pignatti (2012) assesses a more recent 2003-2007 period in Ukraine and finds evidence of a 
further contraction, mostly in the upper part of the distribution, however, highlighting a shift that appears to have taken place between the two periods. The findings in Pham and Reilly (2007) reveal a contraction in the gender wage gap in Vietnam between 1993 and 2002. It is particularly pronounced at the top of the distribution, similar to Pignatti's (2012) findings for Ukraine. Kecmanovic and Barrett (2011) find that the gender wage gap in Serbia contracted during 2001-2005, and the contraction appears to be uniform across the wage distribution. In contrast to the contraction in Ukraine, Vietnam, and Serbia, Pastore and Verashchagina (2011) demonstrate that the gender wage gap in Belarus more than doubled between 1996 and 2006 and did so mostly at the bottom of the distribution. Chi and Li (2008) evaluate the case of China between 1987 and 2004 and find that the gender wage gap widened during this time, also primarily at the bottom of the distribution. $^{2}$ Hence, the empirical evidence reveals a range of outcomes in the changes in the distribution of the gender wage gap in the transition region, underscoring the presence of a complex interplay between economic and institutional mechanisms.

Our understanding of the dynamics of gender inequality in labor markets in Georgia and factors contributing to it is limited. During the 1990s, the gender wage gap at the mean appears to have widened (Yemtsov 2001). At the same time, the collapse that followed the dissolution of the Soviet Union also yielded coping strategies among women that raised their labor force participation rate in the first part of the 1990s as the corresponding rate for men declined. Jashi (2005) finds that, although Georgian women face formidable barriers to economic, political, and social opportunities, their access to these opportunities has improved. The decrease in the gender wage gap during the early 2000s potentially corroborates this argument with respect to the labor markets (Khitarishvili 2009).

This paper is the first study to analyze changes in the gender wage gap in Georgia before and after the 2008 crisis and to evaluate them across the wage distribution. Conducting a distributional analysis enables us to assess the heterogeneity underlying the movements in the mean gender wage gap. This can allow us to assess whether economic forces affect low- and high-earning men and women differently. We employ the recentered influence function quantile decomposition method based on Firpo et al. (2007, 2009). This method decomposes the gap into the composition and wage structure effects for each of the explanatory variables at various percentiles of the wage distribution. This allows us to evaluate how the factors that influenced the gender wage gap differed before and after the recession. In addition, we use the decomposition approach developed in Nopo (2008) to assess the degree to which nonoverlapping supports in the characteristics of men and women may influence our baseline results. Accounting for this possibility may be important in many settings and especially in economies such as Georgia's, which exhibit high occupational and industrial segregation.

The rest of the paper is structured as follows. In Section 2, we present the data summary and analyze the changes that took place in the characteristics of wage workers in Georgia during 2004-2011. Section 3 outlines the implementation of the decomposition methods in Firpo et al. (2007) and Ñopo (2008). Section 4 presents the analysis of the determinants of the gender wage gap at the mean and across the wage distribution and contrasts the results before and after the recession. We discuss the implications of our study in the conclusions. 


\section{Data summary}

We use the Georgian Household Budget Survey (HBS) data for 2004, 2007, and 2011. ${ }^{3}$ The HBS is a quarterly survey of over 3000 households, which follows a rotating panel design (Deaton 1997). Surveyed households remain in the sample for four quarters before being replaced by a new cohort. ${ }^{4}$ The survey covers questions related to individual and household socioeconomic well-being. We limit the sample to 25-55-year-old individuals to avoid issues related to the inclusions of individuals in early retirement and those enrolled in school. Our analysis focuses on wage workers, who comprise close to $40 \%$ of the female and male labor force (Table 1). We evaluate the gender gap only among wage workers because the process of wage determination in their case is likely to be different from other employment categories (Garcia-Mainar and Montuenga-Gomez 2005). ${ }^{5}$ With these restrictions placed on the data, our sample includes 6346 men and 5864 women for a total of 12,210 individuals.

We use contractual monthly wages from primary employment and convert them into 2005 constant Georgian laris (GEL) using the official quarterly consumer price index. The dependent variable in the analysis is the natural log of these wages. Monthly rather than hourly wages are used due to the lack of the data on the exact number of hours worked.

The explanatory variables in the model include age, age-squared, and dummy variables for the level of educational attainment, marital status, skill level, ${ }^{6}$ state sector, industry, urban residence, capital city Tbilisi, nationality, and quarter. In addition, in order to mitigate the likely overestimation in the gender wage gap due to the use of monthly wage data (Brainerd 1998), we include a categorical variable that identifies the blocks of time worked.

The analysis of the characteristics of men and women reveals that compared to their male counterparts, female wage workers tend to be older, more likely to be single, and to live in urban areas or in Tbilisi (Table 1). This picture likely reflects the greater barriers experienced by married women of prime child-bearing age, especially in rural parts of Georgia, tor entering wage employment. Moreover, compared to men, who are more evenly spread out across different industries, women are concentrated in education, health care, and social work, with close to $50 \%$ of female wage workers employed in these industries. Furthermore, women's state sector share in total female employment is higher than men's state sector share in total male employment. Although the remuneration in these industries and in the state sector is below the economy-wide average, the jobs in these sectors offer greater flexibility and stability, characteristics that are viewed to be more important to women due to their reproductive role and household responsibilities (Schmid 2010). In a related point, women work fewer hours than men, also potentially reflecting their preference for more flexible arrangements. We note that women's decisions with respect to the industry of employment and work time arrangements have to be placed in the context of broader social and cultural norms. Possibly as a way of overcoming the labor market constraints that they face, women in Georgia obtain more education than men and proportionately more of them are engaged in high-skilled white-collar occupations, a pattern also observed in other countries of the transition region (World Bank 2012). The proportions of ethnic Georgians among female and male wage workers are similar. 
Table 1 Summary statistics

\begin{tabular}{|c|c|c|c|c|c|c|}
\hline & \multicolumn{3}{|l|}{ Men } & \multicolumn{3}{|c|}{ Women } \\
\hline & 2004 & 2007 & 2011 & 2004 & 2007 & 2011 \\
\hline Share of wage workers in LF & 0.347 & 0.400 & 0.398 & 0.378 & 0.384 & 0.395 \\
\hline \multicolumn{7}{|l|}{ Age categories } \\
\hline $25-34$ & 0.289 & 0.331 & 0.374 & 0.237 & 0.264 & 0.266 \\
\hline $35-44$ & 0.366 & 0.315 & 0.3 & 0.393 & 0.357 & 0.35 \\
\hline $45-55$ & 0.345 & 0.353 & 0.326 & 0.37 & 0.379 & 0.385 \\
\hline \multicolumn{7}{|l|}{ Education } \\
\hline Secondary and below & 0.261 & 0.282 & 0.325 & 0.151 & 0.133 & 0.149 \\
\hline Vocational & 0.255 & 0.206 & 0.188 & 0.268 & 0.244 & 0.252 \\
\hline Higher education & 0.484 & 0.512 & 0.487 & 0.581 & 0.623 & 0.599 \\
\hline \multicolumn{7}{|l|}{ Marriage } \\
\hline Unmarried & 0.181 & 0.223 & 0.183 & 0.378 & 0.413 & 0.344 \\
\hline Married & 0.819 & 0.777 & 0.817 & 0.622 & 0.587 & 0.656 \\
\hline \multicolumn{7}{|l|}{ Nationality } \\
\hline Non-Georgian & 0.115 & 0.092 & 0.066 & 0.107 & 0.094 & 0.075 \\
\hline Georgian & 0.885 & 0.908 & 0.934 & 0.893 & 0.906 & 0.925 \\
\hline \multicolumn{7}{|l|}{ Residence } \\
\hline Rural & 0.334 & 0.303 & 0.357 & 0.275 & 0.231 & 0.258 \\
\hline Urban & 0.666 & 0.697 & 0.643 & 0.725 & 0.769 & 0.742 \\
\hline \multicolumn{7}{|l|}{ Capital city } \\
\hline Not Tbilisi & 0.611 & 0.542 & 0.652 & 0.569 & 0.515 & 0.577 \\
\hline Tbilisi & 0.389 & 0.458 & 0.348 & 0.431 & 0.485 & 0.423 \\
\hline \multicolumn{7}{|l|}{ Working hours } \\
\hline Less than $20 \mathrm{~h}$ & 0.033 & 0.034 & 0.051 & 0.098 & 0.134 & 0.167 \\
\hline $21-40 \mathrm{~h}$ & 0.439 & 0.293 & 0.43 & 0.661 & 0.46 & 0.491 \\
\hline More than $40 \mathrm{~h}$ & 0.476 & 0.599 & 0.449 & 0.229 & 0.39 & 0.313 \\
\hline Seasonal hours & 0.052 & 0.074 & 0.071 & 0.011 & 0.016 & 0.029 \\
\hline \multicolumn{7}{|l|}{ Sector } \\
\hline Private & 0.627 & 0.603 & 0.66 & 0.414 & 0.389 & 0.501 \\
\hline State & 0.373 & 0.397 & 0.34 & 0.586 & 0.611 & 0.499 \\
\hline \multicolumn{7}{|l|}{ Occupation, by skill level } \\
\hline Low-skilled, blue-collar & 0.217 & 0.231 & 0.313 & 0.06 & 0.068 & 0.082 \\
\hline High-skilled, blue-collar & 0.188 & 0.211 & 0.139 & 0.048 & 0.038 & 0.037 \\
\hline Low-skilled, white-collar & 0.141 & 0.129 & 0.169 & 0.209 & 0.207 & 0.257 \\
\hline High-skilled, white-collar & 0.455 & 0.429 & 0.379 & 0.683 & 0.687 & 0.625 \\
\hline \multicolumn{7}{|l|}{ Industry type } \\
\hline Agriculture & 0.053 & 0.05 & 0.042 & 0.01 & 0.014 & 0.012 \\
\hline Mining & 0.011 & 0.013 & 0.038 & 0 & 0.001 & 0.006 \\
\hline Manufacturing & 0.14 & 0.149 & 0.114 & 0.07 & 0.049 & 0.079 \\
\hline Utilities & 0.062 & 0.035 & 0.057 & 0.011 & 0.008 & 0.009 \\
\hline Construction & 0.073 & 0.154 & 0.11 & 0.001 & 0.017 & 0.006 \\
\hline Trade & 0.12 & 0.109 & 0.131 & 0.112 & 0.142 & 0.128 \\
\hline Hotels and restaurants & 0.012 & 0.011 & 0.011 & 0.032 & 0.029 & 0.034 \\
\hline Transport & 0.106 & 0.11 & 0.092 & 0.042 & 0.022 & 0.031 \\
\hline
\end{tabular}


Table 1 Summary statistics (Continued)

\begin{tabular}{lllllll}
\hline Finance & 0.018 & 0.025 & 0.034 & 0.025 & 0.034 & 0.021 \\
Real estate & 0.047 & 0.058 & 0.047 & 0.043 & 0.043 & 0.021 \\
PA and defense & 0.195 & 0.153 & 0.181 & 0.099 & 0.064 & 0.083 \\
Education & 0.07 & 0.056 & 0.065 & 0.359 & 0.328 & 0.321 \\
Health and social work & 0.025 & 0.024 & 0.024 & 0.126 & 0.177 & 0.133 \\
Culture & 0.058 & 0.052 & 0.046 & 0.054 & 0.048 & 0.073 \\
Private households & 0 & 0.002 & 0.009 & 0.013 & 0.021 & 0.04 \\
International organizations & 0.01 & 0.001 & 0.001 & 0.003 & 0.003 & 0.003 \\
Number of observations & 2072 & 2040 & 2234 & 2134 & 1793 & 1937 \\
\hline
\end{tabular}

Notes:: weighted proportions, unless indicated otherwise; columns for each category add up to one Source: GHBS data

Between 2004 and 2011, the characteristics of wage workers changed, reflecting shifts in the structure of the Georgian economy, the impact of the recession, and population demographics. Some of these shifts persisted throughout this period, whereas others were cyclical in nature with the recession separating 2004-2011 into the pre-recession and post-recession periods (2004-2007 and 2007-2011). ${ }^{7}$

During 2004-2011, male wage workers became younger, potentially reflecting changing demographic characteristics, declining importance of experience in wage employment, and/or earlier retirement. Proportionately fewer men live in Tbilisi, pointing to the expansion of wage employment opportunities for men in other parts of Georgia. Men's engagement in seasonal work increased, potentially driven by increased seasonal demand in construction. Also reflecting broader shifts in the structure of the Georgian economy, the proportion of men with vocational education and the proportion of men engaged in high-skilled white-collar occupations declined throughout 2004-2011. Other changes were cyclical in nature. For example, construction, transport, and manufacturing expanded before the recession and contracted after. Similar cyclicality in men's employment is visible in the state sector, with the proportion of men in the state sector increasing from $37 \%$ in 2004 to $40 \%$ in 2007, before shrinking to $34 \%$ in 2011 . In addition, the changes in the number of hours worked exhibited strong cyclicality: whereas between 2004 and 2007, the proportion of men working $40 \mathrm{~h}$ or more increased from 48 to $60 \%$, after 2007, it decreased to the below-2004 level of $45 \%$.

Changes in women's characteristics also reflect a combination of broader economic shifts and cyclical patterns (Table 1). Similar to men, the proportion of female wage workers in urban areas fell, once again potentially reflecting the economic expansion in rural regions of Georgia. Also, the proportion of women working in the state sector first increased between 2004 and 2007 but then sharply dropped to the below-2004 level after the recession. The magnitude of the increase and especially the magnitude of the decline were more substantial for women than for men. On the other hand, unlike men, women did not experience notable changes in their educational composition, especially in vocational education. Moreover, their proportion in low-skilled white-collar occupations increased as the proportion of high-skilled white-collar occupations declined.

These findings highlight that, whereas male wage employment appears to have expanded in the direction of blue-collar occupations, women remained in white-collar occupations, which commonly require education beyond the secondary level. This 
evidence complements the finding that most of the reshuffling in the industrial composition of female wage employment took place within the service sectors. In particular, culture and health and social work expanded, while other service sectors, such as public administration and defense, and education contracted, especially after 2007. In addition, similar to men, women's work hours followed a cyclical pattern. However, the pre-recession increase was greater and the post-recession drop was smaller for women than for men. Therefore, it appears that women's characteristics have improved relative to men's during the expansion and did not deteriorate to the same extent as men's as a result of the recession.

The latter point is also visible in the movement of real wages for men and women before and after the recession. Real wages grew and did so faster for women than for men until 2009, after which they stagnated for women and declined for men as a result of the recession (Fig. $1^{8}$ ).

Between 2004 and 2007, the growth rate in women's wages was $62 \%$ compared to men's 48 \%. Between 2007 and 2011, women's wage growth slowed down to $26 \%$ whereas men's wage growth reached only $9 \%$. These changes were associated with heterogeneous patterns of wage movement for different groups of men and women (Table 2). In the case of men, wages of workers in rural areas and outside of the capital city grew faster during the expansion between 2004 and 2007, consistent with the growth in the proportion of workers that we observed in rural areas. Moreover, 45-54year-old male wage workers benefitted the most from wage growth, but they were also hit the hardest by the recession. The recession hurt the wages of male workers with vocational education and those working in high-skill blue-collar occupations especially hard. The growth rate of men's wages varied across different sectors of the economy before and after the crisis. For example, between 2004 and 2007, men's wages grew especially fast in utilities, finance, and public administration and defense. However, these sectors were hit the hardest after 2007, in the case of the finance sector resulting in a $19 \%$ contraction in men's wages. Wages in manufacturing, construction, and agriculture were also strongly affected by the recession.

Wage movements were somewhat different for women. For example, it is the wages of urban women and women working in Tbilisi that grew the fastest between 2004 and

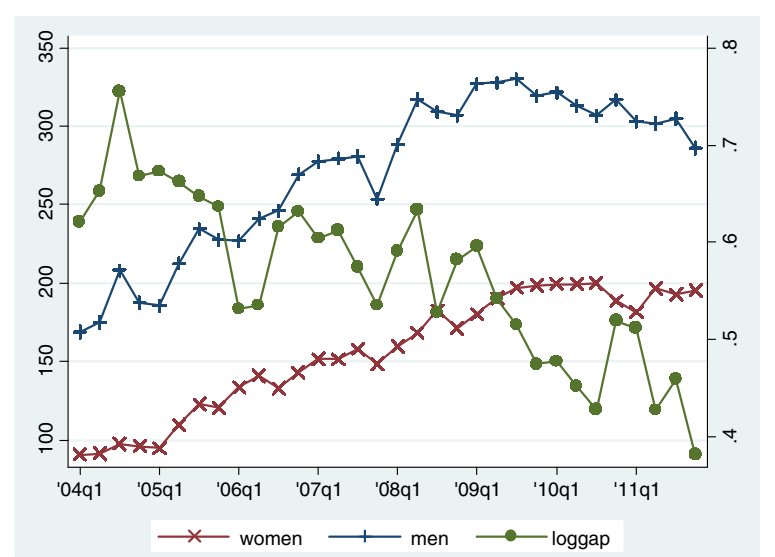

Fig. 1 Real wages (in 2005 constant GEL) and gender wage gap in log points, ${ }^{8}$ 2004-2011. Source: GHBS data 
Table 2 Mean wages and growth rates in the wages of men and women

\begin{tabular}{|c|c|c|c|c|c|c|c|c|c|c|}
\hline & \multicolumn{5}{|l|}{ Men } & \multicolumn{5}{|c|}{ Women } \\
\hline & \multicolumn{3}{|c|}{ Wages } & \multicolumn{2}{|c|}{ Growth Rates } & \multicolumn{3}{|c|}{ Wages } & \multicolumn{2}{|c|}{ Growth rates } \\
\hline & 2004 & 2007 & 2011 & $\begin{array}{l}2004- \\
2007\end{array}$ & $\begin{array}{l}2007- \\
2011\end{array}$ & 2004 & 2007 & 2011 & $\begin{array}{l}2004- \\
2007\end{array}$ & $\begin{array}{l}2007- \\
2011\end{array}$ \\
\hline Overall & 184.7 & 272.8 & 298.7 & 0.48 & 0.09 & 94 & 152.6 & 192 & 0.62 & 0.26 \\
\hline \multicolumn{11}{|l|}{ Age categories } \\
\hline $25-34$ & 217.2 & 279.9 & 320.4 & 0.29 & 0.14 & 105 & 159.5 & 218.7 & 0.52 & 0.37 \\
\hline $35-44$ & 177.5 & 274.1 & 313.8 & 0.54 & 0.14 & 88.9 & 159.7 & 190.4 & 0.80 & 0.19 \\
\hline $45-55$ & 165.1 & 265 & 259.8 & 0.61 & -0.02 & 92.3 & 141 & 175.3 & 0.53 & 0.24 \\
\hline \multicolumn{11}{|l|}{ Education } \\
\hline Secondary and below & 149.6 & 200.3 & 224.5 & 0.34 & 0.12 & 94.7 & 109.5 & 122.3 & 0.16 & 0.12 \\
\hline Vocational & 158.8 & 224.3 & 221.5 & 0.41 & -0.01 & 73.7 & 104.8 & 129.7 & 0.42 & 0.24 \\
\hline Higher education & 217.3 & 332.3 & 377.5 & 0.53 & 0.14 & 103.1 & 180.5 & 235 & 0.75 & 0.30 \\
\hline \multicolumn{11}{|l|}{ Marriage } \\
\hline Unmarried & 192.1 & 247.4 & 285.8 & 0.29 & 0.16 & 109.2 & 168.3 & 221.7 & 0.54 & 0.32 \\
\hline Married & 183.1 & 280.1 & 301.7 & 0.53 & 0.08 & 84.7 & 141.5 & 176.4 & 0.67 & 0.25 \\
\hline \multicolumn{11}{|l|}{ Nationality } \\
\hline Non-Georgian & 177.8 & 196.2 & 234.1 & 0.10 & 0.19 & 86.2 & 144.3 & 158.8 & 0.67 & 0.10 \\
\hline Georgian & 185.6 & 280.6 & 303.3 & 0.51 & 0.08 & 94.9 & 153.4 & 194.7 & 0.62 & 0.27 \\
\hline \multicolumn{11}{|l|}{ Residence } \\
\hline Rural & 126.9 & 198.3 & 232.5 & 0.56 & 0.17 & 68.9 & 104.4 & 135.1 & 0.52 & 0.29 \\
\hline Urban & 213.6 & 305.3 & 335.3 & 0.43 & 0.10 & 103.5 & 167 & 211.6 & 0.61 & 0.27 \\
\hline \multicolumn{11}{|l|}{ Capital city } \\
\hline Not Tbilisi & 147.7 & 223.9 & 247 & 0.52 & 0.10 & 76.4 & 114.8 & 148.9 & 0.50 & 0.30 \\
\hline Tbilisi & 242.9 & 330.7 & 394.6 & 0.36 & 0.19 & 117.2 & 192.6 & 249.9 & 0.64 & 0.30 \\
\hline \multicolumn{11}{|l|}{ Working hours } \\
\hline Less than 20 hours & 96.5 & 120.9 & 141.3 & 0.25 & 0.17 & 54.5 & 82.6 & 118.1 & 0.52 & 0.43 \\
\hline $21-40$ hours & 160.9 & 264.2 & 289.6 & 0.64 & 0.10 & 87.5 & 141.2 & 189.3 & 0.61 & 0.34 \\
\hline More than 40 hours & 212.5 & 292.4 & 342.1 & 0.38 & 0.17 & 129.6 & 192.5 & 243 & 0.49 & 0.26 \\
\hline Seasonal hours & 186.1 & 218.2 & 192.7 & 0.17 & -0.12 & 90.7 & 95.3 & 112.7 & 0.05 & 0.18 \\
\hline \multicolumn{11}{|l|}{ Sector } \\
\hline Private & 222.7 & 275.4 & 289.9 & 0.24 & 0.05 & 129 & 169.9 & 192 & 0.32 & 0.13 \\
\hline State & 120.8 & 268.9 & 315.8 & 1.23 & 0.17 & 69.2 & 141.5 & 192 & 1.04 & 0.36 \\
\hline \multicolumn{11}{|l|}{ Occupation, by skill level } \\
\hline Low-skilled, blue-collar & 167.5 & 197.2 & 237.4 & 0.18 & 0.20 & 81.6 & 91.8 & 126.6 & 0.13 & 0.38 \\
\hline High-skilled, blue-collar & 162.4 & 223.1 & 225.3 & 0.37 & 0.01 & 91.8 & 96.9 & 115.9 & 0.06 & 0.20 \\
\hline Low-skilled, white-collar & 163.9 & 193 & 226.1 & 0.18 & 0.17 & 105.6 & 144.4 & 150.1 & 0.37 & 0.04 \\
\hline High-skilled, white-collar & 208.6 & 362 & 407.5 & 0.74 & 0.13 & 91.7 & 164.1 & 221.9 & 0.79 & 0.35 \\
\hline \multicolumn{11}{|l|}{ Industry type } \\
\hline Agriculture & 104.5 & 136.9 & 121 & 0.31 & -0.12 & 82.8 & 109.2 & 69.6 & 0.32 & -0.36 \\
\hline Mining & 352.9 & 332.6 & 355.3 & -0.06 & 0.07 & & 102.2 & 216.6 & & 1.12 \\
\hline Manufacturing & 180.9 & 252.8 & 232.3 & 0.40 & -0.08 & 122.2 & 149.8 & 145.6 & 0.23 & -0.03 \\
\hline Utilities & 184.9 & 296.7 & 312.2 & 0.60 & 0.05 & 227.8 & 144.6 & 267.1 & -0.37 & 0.85 \\
\hline Construction & 243.8 & 316.7 & 293.5 & 0.30 & -0.07 & 329.7 & 296.1 & 265.4 & -0.10 & -0.10 \\
\hline Trade & 187.4 & 237 & 291.4 & 0.26 & 0.23 & 120.4 & 138.2 & 172.3 & 0.15 & 0.25 \\
\hline
\end{tabular}


Table 2 Mean wages and growth rates in the wages of men and women (Continued)

\begin{tabular}{lllllllllll}
\hline Hotels and restaurants & 227.6 & 238.4 & 270.8 & 0.05 & 0.14 & 138.5 & 191.5 & 137.4 & 0.38 & -0.28 \\
Transport & 219.5 & 240.8 & 311.1 & 0.10 & 0.29 & 99 & 307.6 & 281.8 & 2.11 & -0.08 \\
Finance & 301.9 & 577.5 & 466.7 & 0.91 & -0.19 & 170.2 & 444.8 & 434.6 & 1.61 & -0.02 \\
Real estate & 181.6 & 253.4 & 286.7 & 0.40 & 0.13 & 99.3 & 156.8 & 291.2 & 0.58 & 0.86 \\
PA and defense & 145.4 & 372.1 & 404.9 & 1.56 & 0.09 & 88.3 & 269.5 & 355.5 & 2.05 & 0.32 \\
Education & 109 & 137.2 & 175.3 & 0.26 & 0.28 & 74.9 & 100 & 156.5 & 0.34 & 0.57 \\
Health and social work & 168.5 & 166.3 & 233.9 & -0.01 & 0.41 & 67.7 & 129.3 & 181 & 0.91 & 0.40 \\
Culture & 208.7 & 237.4 & 279.5 & 0.14 & 0.18 & 80.2 & 139.2 & 168.8 & 0.74 & 0.21 \\
Private households & 87.7 & 134.3 & 202.6 & 0.53 & 0.51 & 160.4 & 127.7 & 154.6 & -0.20 & 0.21 \\
International & 599.8 & 151.5 & 484.3 & -0.75 & 2.20 & 192 & 495.5 & 505.6 & 1.58 & 0.02 \\
organizations & & & & & & & & & &
\end{tabular}

Notes: survey-weighted means

Source: GHBS data

2007, suggesting that they benefitted more than rural women from the economic expansion, possibly linked to the expansion of the state sector that tends to be concentrated in urban areas. Age patterns also varied. Unlike men, during this period, the wage growth was the fastest among 35-44-year-old women (at $80 \%$, it was the fastest growth rate of all age categories of men and women). However, after 2007, their wage growth also slowed down the most. In terms of education, the wages of female workers with secondary education or lower performed the worst during both periods. Sectoral wage movements varied for women, as well. For example, in public administration and defense, between 2004 and 2007, women's wages grew faster than men's wages (205\% compared to $156 \%$ ), suggesting that the overall gender wage gap in this sector contracted between 2004 and 2007. This contraction continued after the recession as women's wages kept growing at $32 \%$ whereas men's wages largely stagnated at $9 \%$ growth. Also, between 2004 and 2007, women's wages in health and social work and culture grew considerably and, in the case of education, continued growing after the recession at $57 \%$, more than twice the economy-wide female wage-growth rate of $26 \%$. On the other hand, the female wages in other sectors, which rose substantially during the expansion, such as finance and transport, contracted after the recession. Hotels and restaurants, in which female presence is strong, took a particular hit as female wages shrank by $28 \%$.

These changes in the wages of men and women resulted in a decline in the gender wage gap between 2004 and 2011 with a statistically insignificant decrease between 2004 and 2007 and a sizable drop thereafter.

Behind this decline in the gender wage gap at the mean lie shifts in the shape of the gender wage gap across the wage distribution before and after the recession (Fig. 2). ${ }^{9}$ Indeed, the lack of a statistical change in the gap between 2004 and 2007 masks a switch in the shape of the gender wage gap distribution. In 2004, the gender wage gap was the lowest at the bottom and highest at the top of the distribution, consistent with the presence of the glass ceiling effect, which reflects the greater barriers for advancement among high-earning women (Christofides et al. 2013). In 2007, on the other hand, the shape was reversed in that the gap was the highest at the bottom of the distribution and lowest at the top. Finally, the decrease in the gender wage gap at the mean observed by 2011 was associated with the downward shift in the gender wage gap all across the wage distribution. Because the drop was more substantial at the bottom and 


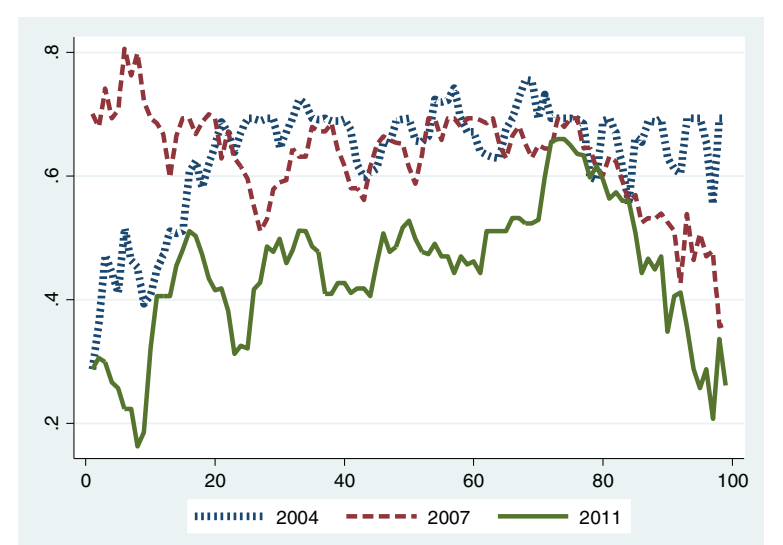

Fig. 2 Distribution of the raw gender wage gap in log points: 2004, 2007, and 2011. Source: GHBS data

top of the distribution compared to the middle, the gender wage gap took on an inverted-U shape. These shifts reveal the presence of different forces behind the developments before and after the recession, which we examine in this paper.

\section{Methodology}

In our analysis, we employ the recentered influence function (RIF) decomposition approach proposed in Firpo et al. (2007), from now on FFL. The approach has two important advantages. The first is that it allows an evaluation of the impact of explanatory variables on unconditional quantiles, which makes inferences applicable to the full sample of wage workers rather than its particular segments. The second advantage is that unlike other popular methods of decomposition across the wage distribution (Juhn et al. 1993; Machado and Mata 2005), the FFL approach allows for the decomposition into the composition (explained) component and the structural (unexplained) component for each of the explanatory variables. The latter advantage enables us to identify specific factors that explain the gap across different quantiles before and after the recession.

The FFL decomposition method involves several steps. First, at any quantile, the wage gap is decomposed into the composition and wage structure components. This step can be expressed as follows:

$$
v\left(Y_{m}\right)-v\left(Y_{f}\right)=\left[v\left(Y_{m}\right)-v\left(Y_{c}\right)\right]+\left[v\left(Y_{c}\right)-v\left(Y_{f}\right)\right]
$$

where $v(Y)$ is a quantile of a wage distribution $Y$; $Y_{m}$ and $Y_{f}$ are male and female wage distributions, respectively; and $Y_{c}$ is the counterfactual distribution of the wages that women would earn if they had the same returns to their characteristics as men. ${ }^{10}$ The first component of the decomposition can be viewed as the composition portion of the gap due to the differences in characteristics and the second component as the wage structure effect due to the differences in the returns to these characteristics.

The counterfactual $Y_{c}$ is derived by reweighting $Y_{m}$ so that $Y_{c}=\theta Y_{m}$, where $\theta_{i}=$ $\frac{1-p\left(Z_{i}\right)}{p\left(Z_{i}\right)} \frac{p}{1-p}$ with $p\left(Z_{i}\right)$ being the probability of an individual being a male given $Z_{i}$ and $p$ being the proportion of males in the sample. We estimate the counterfactual distribution of wages that women would earn if they had the same returns to characteristics as 
men using the probit model. In the model, the probability of being a man is estimated to be a function of explanatory variables used in the wage quantile estimations (age, age squared, education, marital status, skill level, state sector, industry, urban residence, Tbilisi, work hours, nationality, and quarterly dummy variables) and, in addition, interaction terms between education and skills, and education and age.

In the second step, wage quantiles are linearly approximated using the recentered influence function as $\widehat{\operatorname{RIF}}\left(Y_{k} ; \hat{q}_{\tau}\right)=X_{k} \hat{\beta}_{k}, k=m, f, c$, where $\widehat{\operatorname{RIF}}\left(Y_{k} ; \hat{q}_{\tau}\right)$ represents the RIF estimate of the $\tau$ th quantile and $\hat{\beta}_{k}$ is the unconditional marginal effect of $X_{k}$ on the quantile $q_{\tau}$. Then, the quantile decomposition can be expressed as follows:

$$
\hat{q}_{\tau}\left(Y_{m}\right)-\hat{q}_{\tau}\left(Y_{f}\right)=\left\{\bar{X}_{f}\left(\hat{\beta}_{c}-\hat{\beta}_{f}\right)+\hat{R}_{\tau s}\right\}+\left\{\left(\bar{X}_{m} \hat{\beta}_{m}-\bar{X}_{f} \hat{\beta}_{c}\right)+\hat{R}_{\tau c}\right\},
$$

where $\hat{R}_{\tau s}$ and $\hat{R}_{\tau c}$ are the approximation errors of the structure and composition effects, respectively. This approach is directly comparable to the Oaxaca-Blinder approach (Oaxaca 1973; Blinder 1973) and is equivalent to it at the mean of the wage distribution (Firpo et al. 2007).

A potential limitation of the FFL decomposition approach is that it assumes that men and women share the same support in their characteristics or, at minimum, that the coefficients of the wage equations are similar between the individuals in and out of the common support. In many settings, especially in economies exhibiting high occupational and industrial segregation, men's and women's characteristics may not perfectly overlap. For example, as Table 1 indicates, there were no miners among female wage workers in 2004 and, similarly, there were almost no men working as domestic helpers in private households. As a result, the model may be misspecified. To assess the degree to which this may pose a problem, we use the approach developed by Nopo (2008), which utilizes statistical matching to separate men and women into groups that share a common support and groups (one for each gender) that include individuals whose characteristics do not match those of the opposite gender. The total gap can then be decomposed into the composition $\left(\Delta_{\mathrm{x}}\right)$ and wage structure $\left(\Delta_{\mathrm{o}}\right)$ components analogous to the Oaxaca-Blinder counterparts but defined only over the common support, and the components, which are attributed to the differences in the characteristics between individuals who were matched and those who were not. In particular, $\Delta_{\mathrm{m}}$ corresponds to the contribution of the differences in the characteristics of males who were matched to female characteristics (and hence share the support with them) and those who were not matched with female characteristics (and hence are not in the common support). Similarly, $\Delta_{\mathrm{f}}$ corresponds to the contribution of the differences in the characteristics of females who were matched to male characteristics and those who were not matched with male characteristics. Hence, the total gap $\Delta$ is $\Delta_{\mathrm{x}}+\Delta_{\mathrm{m}}+\Delta_{\mathrm{f}}+\Delta_{\mathrm{o}}$.

\section{Estimation and results}

\subsection{Before the recession}

Between 2004 and 2007, the Georgian economy expanded. This expansion was associated with a statistically insignificant decrease in the conditional gender wage gap at the mean from 0.64 to $0.63 \log$ points (Tables 3 and 4). ${ }^{11}$ However, the lack of change at the mean masked the reversal in the shape of the distribution of the gender wage gap from upward sloping in 2004 to downward sloping in 2007. Indeed, whereas in 2004, 
Table 3 Decomposition of the gender wage gap at selected quantiles, 2004

\begin{tabular}{|c|c|c|c|c|c|c|c|c|c|c|c|c|}
\hline \multirow[t]{2}{*}{ Variables } & \multicolumn{6}{|c|}{ Composition } & \multicolumn{6}{|l|}{ Structure } \\
\hline & Mean & 10th & 25th & 50th & 75th & 90th & Mean & 10th & 25th & 50th & 75th & 90th \\
\hline \multirow[t]{2}{*}{$\overline{\text { Vocational }^{a}}$} & 0.0278 & 0.0145 & 0.0104 & 0.0250 & $0.103^{*}$ & 0.0608 & -0.0151 & -0.0360 & 0.00596 & -0.00163 & -0.0819 & -0.0260 \\
\hline & $(0.0195)$ & $(0.0416)$ & $(0.0343)$ & $(0.0302)$ & $(0.0544)$ & $(0.0640)$ & $(0.0261)$ & $(0.0479)$ & $(0.0432)$ & $(0.0388)$ & $(0.0602)$ & $(0.0741)$ \\
\hline \multirow[t]{2}{*}{ Higher education } & 0.0100 & -0.171 & -0.0643 & 0.0774 & $0.234^{*}$ & 0.00967 & -0.108 & -0.00892 & -0.109 & $-0.172^{*}$ & $-0.258^{*}$ & 0.0336 \\
\hline & $(0.0547)$ & $(0.139)$ & $(0.112)$ & $(0.0769)$ & $(0.119)$ & $(0.169)$ & $(0.0782)$ & $(0.167)$ & $(0.127)$ & $(0.101)$ & $(0.147)$ & $(0.203)$ \\
\hline \multirow[t]{2}{*}{ Age } & -0.492 & -4.420 & -5.144 & -3.614 & 1.522 & 4.844 & -0.660 & 0.826 & 2.653 & 2.292 & -2.392 & -5.355 \\
\hline & $(1.631)$ & $(4.022)$ & (3.639) & $(2.475)$ & $(2.557)$ & $(4.777)$ & $(2.012)$ & $(4.440)$ & $(3.937)$ & $(2.821)$ & $(3.214)$ & $(5.448)$ \\
\hline \multirow[t]{2}{*}{ Age-squared } & 0.248 & 2.152 & 2.632 & 1.800 & -0.722 & -2.315 & 0.139 & -0.694 & -1.480 & -1.233 & 0.965 & 2.424 \\
\hline & $(0.841)$ & $(2.154)$ & $(1.917)$ & $(1.252)$ & $(1.318)$ & $(2.378)$ & $(1.042)$ & $(2.347)$ & $(2.085)$ & $(1.451)$ & $(1.651)$ & $(2.733)$ \\
\hline \multirow[t]{2}{*}{ Marriage } & $0.118^{* *}$ & $0.225^{* *}$ & $0.241^{* *}$ & $0.220^{* * *}$ & 0.134 & -0.101 & 0.00214 & -0.137 & $-0.177^{*}$ & -0.0789 & 0.0932 & 0.238 \\
\hline & $(0.0554)$ & $(0.107)$ & $(0.0950)$ & $(0.0794)$ & $(0.0966)$ & $(0.171)$ & $(0.0659)$ & $(0.107)$ & $(0.108)$ & $(0.0800)$ & $(0.114)$ & $(0.184)$ \\
\hline \multirow[t]{2}{*}{ High-skill blue-collar ${ }^{b}$} & -0.00432 & 0.0115 & -0.00661 & -0.000288 & -0.0212 & -0.00235 & 0.00304 & 0.0125 & 0.00526 & 0.00248 & -0.00127 & -0.00797 \\
\hline & $(0.0110)$ & $(0.0227)$ & $(0.0183)$ & $(0.0167)$ & $(0.0139)$ & $(0.0186)$ & $(0.00694)$ & $(0.0163)$ & $(0.0129)$ & $(0.00928)$ & $(0.0113)$ & $(0.0128)$ \\
\hline \multirow[t]{2}{*}{ Low-skill white-collar } & $-0.0481^{* * *}$ & -0.0760 & $-0.149^{* * *}$ & 0.000212 & -0.0176 & -0.0352 & 0.0189 & 0.0720 & $0.0954^{* *}$ & -0.0338 & -0.0236 & 0.0290 \\
\hline & $(0.0170)$ & $(0.0603)$ & $(0.0425)$ & $(0.0228)$ & $(0.0346)$ & $(0.0430)$ & $(0.0260)$ & $(0.0723)$ & $(0.0483)$ & $(0.0341)$ & $(0.0477)$ & $(0.0608)$ \\
\hline \multirow[t]{2}{*}{ High-skill white-collar } & $-0.219^{* * *}$ & -0.333 & $-0.398^{* * *}$ & -0.108 & $-0.250^{* *}$ & 0.0193 & $0.167^{*}$ & 0.326 & $0.308^{*}$ & 0.120 & 0.0850 & -0.158 \\
\hline & $(0.0604)$ & $(0.211)$ & $(0.130)$ & $(0.0777)$ & $(0.111)$ & $(0.136)$ & $(0.0952)$ & $(0.264)$ & $(0.167)$ & $(0.111)$ & $(0.140)$ & $(0.190)$ \\
\hline \multirow[t]{2}{*}{ Mining $^{c}$} & $0.0102^{* * *}$ & $0.0126^{* * *}$ & $0.00747^{* * *}$ & $0.0107^{* * *}$ & $0.00745^{* *}$ & $0.0102^{*}$ & 0 & 0 & 0 & 0 & 0 & 0 \\
\hline & $(0.00204)$ & $(0.00300)$ & $(0.00205)$ & $(0.00221)$ & $(0.00329)$ & $(0.00546)$ & (0) & (0) & (0) & (0) & (0) & (0) \\
\hline \multirow[t]{2}{*}{ Manufacturing } & -0.00210 & 0.0126 & -0.0302 & 0.0150 & -0.0138 & 0.0122 & $0.0502^{* * *}$ & $0.112^{* * *}$ & $0.0747^{* * *}$ & 0.0305 & $0.0446^{*}$ & 0.0106 \\
\hline & $(0.0121)$ & $(0.0430)$ & $(0.0211)$ & $(0.0172)$ & $(0.0166)$ & $(0.0167)$ & $(0.0148)$ & $(0.0346)$ & $(0.0236)$ & $(0.0187)$ & $(0.0236)$ & $(0.0239)$ \\
\hline \multirow[t]{2}{*}{ Utilities } & $0.0186^{* * *}$ & $0.0509^{* * *}$ & 0.0129 & $0.0182^{*}$ & 0.00229 & 0.00908 & 0.000933 & $0.0170^{* * *}$ & $0.00961^{* *}$ & 0.000435 & -0.00354 & -0.00846 \\
\hline & $(0.00654)$ & $(0.0181)$ & $(0.00925)$ & $(0.00950)$ & $(0.00816)$ & $(0.0107)$ & $(0.00287)$ & $(0.00564)$ & $(0.00431)$ & $(0.00345)$ & $(0.00493)$ & $(0.00824)$ \\
\hline \multirow[t]{2}{*}{ Construction } & $0.0427^{* * *}$ & $0.0745^{* * *}$ & $0.0340^{* * *}$ & $0.0482^{* * *}$ & $0.0330^{* * *}$ & $0.0237^{*}$ & 0.000160 & $0.00221^{* * *}$ & $0.00166^{* * *}$ & 0.000257 & $6.65 e-05$ & -0.00136 \\
\hline & $(0.00821)$ & $(0.0203)$ & $(0.0119)$ & $(0.0111)$ & $(0.00992)$ & $(0.0129)$ & $(0.000521)$ & $(0.000704)$ & $(0.000567)$ & $(0.000484)$ & $(0.000704)$ & $(0.00152)$ \\
\hline
\end{tabular}


Table 3 Decomposition of the gender wage gap at selected quantiles, 2004 (Continued)

\begin{tabular}{|c|c|c|c|c|c|c|c|c|c|c|c|c|}
\hline \multirow[t]{2}{*}{$\overline{\text { Trade }}$} & $-0.0377^{* *}$ & -0.0779 & $-0.0755^{* *}$ & -0.0118 & -0.0332 & 0.00397 & $0.0853^{* * *}$ & $0.187^{* * *}$ & $0.129^{* * *}$ & $0.0634^{*}$ & $0.0702^{*}$ & 0.00879 \\
\hline & $(0.0162)$ & $(0.0542)$ & $(0.0323)$ & $(0.0213)$ & $(0.0254)$ & $(0.0340)$ & $(0.0239)$ & $(0.0593)$ & $(0.0426)$ & $(0.0326)$ & $(0.0407)$ & $(0.0451)$ \\
\hline \multirow[t]{2}{*}{ Hotels and restaurants } & $-0.0247^{* * *}$ & $-0.0424^{* * *}$ & $-0.0339^{* * *}$ & $-0.0249^{* * *}$ & $-0.0263^{* *}$ & -0.000341 & $0.0301^{* * *}$ & $0.0522^{* * *}$ & $0.0355^{* * *}$ & $0.0322^{* * *}$ & $0.0346^{* *}$ & 0.00452 \\
\hline & $(0.00488)$ & $(0.0156)$ & $(0.00970)$ & $(0.00672)$ & $(0.0123)$ & $(0.0159)$ & $(0.00777)$ & $(0.0172)$ & $(0.0120)$ & (0.00998) & $(0.0163)$ & $(0.0232)$ \\
\hline \multirow[t]{2}{*}{ Transport } & $0.0182^{*}$ & 0.0328 & -0.000949 & $0.0405^{* * *}$ & 0.0139 & 0.00844 & $0.0418^{* * *}$ & $0.0763^{* * *}$ & $0.0546^{* * *}$ & $0.0332^{* * *}$ & $0.0278^{*}$ & $0.0222^{*}$ \\
\hline & $(0.00942)$ & $(0.0318)$ & $(0.0158)$ & $(0.0136)$ & $(0.0114)$ & $(0.0115)$ & $(0.00941)$ & $(0.0232)$ & $(0.0163)$ & $(0.0124)$ & $(0.0166)$ & $(0.0132)$ \\
\hline \multirow[t]{2}{*}{ Finance } & -0.00576 & -0.00474 & -0.00880 & 0.000706 & -0.00737 & 0.000871 & 0.00922 & 0.0206 & 0.0147 & 0.00648 & 0.0102 & -0.00350 \\
\hline & $(0.00579)$ & $(0.0153)$ & $(0.00917)$ & $(0.00531)$ & $(0.00797)$ & $(0.0125)$ & $(0.00853)$ & $(0.0191)$ & $(0.0121)$ & $(0.00814)$ & $(0.0127)$ & $(0.0195)$ \\
\hline \multirow[t]{2}{*}{ Real estate } & -0.00815 & -0.0139 & $-0.0279^{* *}$ & -0.00218 & -0.0133 & 0.00741 & $0.0348^{* * *}$ & $0.0828^{* * *}$ & $0.0524^{* * *}$ & $0.0283^{* *}$ & $0.0295^{*}$ & -0.0111 \\
\hline & $(0.00654)$ & $(0.0213)$ & $(0.0135)$ & $(0.00841)$ & $(0.0133)$ & $(0.0121)$ & $(0.0105)$ & $(0.0254)$ & $(0.0180)$ & $(0.0128)$ & $(0.0175)$ & $(0.0186)$ \\
\hline \multirow[t]{2}{*}{ Public adm and defense } & 0.0121 & 0.0323 & $-1.23 e-05$ & -0.00609 & -0.00704 & 0.0385 & $0.0571^{* * *}$ & $0.163^{* * *}$ & $0.0753^{*}$ & 0.0186 & 0.0327 & 0.00977 \\
\hline & $(0.0173)$ & $(0.0618)$ & $(0.0335)$ & $(0.0260)$ & $(0.0225)$ & $(0.0237)$ & $(0.0216)$ & $(0.0538)$ & $(0.0407)$ & $(0.0266)$ & $(0.0307)$ & $(0.0301)$ \\
\hline \multirow[t]{2}{*}{ Education } & $-0.128^{* *}$ & $-0.453^{* * *}$ & -0.160 & -0.0422 & -0.0675 & 0.0189 & $0.210^{* * *}$ & $0.593^{* * *}$ & 0.172 & 0.0627 & $0.193^{*}$ & 0.0488 \\
\hline & $(0.0516)$ & $(0.170)$ & $(0.114)$ & $(0.0527)$ & $(0.0715)$ & $(0.0876)$ & $(0.0768)$ & $(0.195)$ & $(0.138)$ & $(0.0957)$ & $(0.112)$ & $(0.127)$ \\
\hline \multirow[t]{2}{*}{ Health and social work } & $-0.0486^{* *}$ & $-0.139^{* *}$ & -0.0707 & -0.0365 & -0.00758 & 0.0103 & $0.103^{* * *}$ & $0.216^{* * *}$ & $0.123^{* *}$ & $0.0714^{*}$ & 0.0593 & 0.0310 \\
\hline & $(0.0247)$ & $(0.0656)$ & $(0.0445)$ & $(0.0263)$ & $(0.0271)$ & $(0.0267)$ & $(0.0333)$ & $(0.0759)$ & $(0.0535)$ & $(0.0409)$ & $(0.0435)$ & $(0.0485)$ \\
\hline \multirow[t]{2}{*}{ Culture } & -0.0121 & -0.0374 & $-0.0645^{* * *}$ & 0.000609 & -0.00318 & 0.00497 & $0.0365^{* * *}$ & $0.0936^{* * *}$ & $0.0819^{* * *}$ & 0.0207 & 0.0142 & 0.00192 \\
\hline & $(0.00878)$ & $(0.0291)$ & $(0.0187)$ & $(0.0104)$ & $(0.0118)$ & $(0.0169)$ & $(0.0131)$ & $(0.0320)$ & $(0.0234)$ & $(0.0160)$ & $(0.0203)$ & $(0.0236)$ \\
\hline \multirow[t]{2}{*}{ Private households } & $-0.00859^{* *}$ & $-0.0283^{* *}$ & $-0.0305^{* *}$ & 0.00423 & 0.00300 & 0.00438 & $0.00795^{*}$ & $0.0286^{* *}$ & $0.0321^{* *}$ & -0.00536 & -0.00379 & -0.00642 \\
\hline & $(0.00423)$ & $(0.0140)$ & $(0.0136)$ & $(0.00391)$ & $(0.00306)$ & $(0.00337)$ & $(0.00469)$ & $(0.0144)$ & $(0.0143)$ & $(0.00544)$ & $(0.00596)$ & $(0.00645)$ \\
\hline \multirow[t]{2}{*}{ International org } & 0.00497 & $0.00565^{*}$ & 0.00153 & $0.00602^{* * *}$ & 0.00329 & 0.000102 & $0.00377^{* *}$ & $0.00357^{*}$ & 0.00159 & 0.00146 & $0.00495^{* * *}$ & 0.00411 \\
\hline & $(0.00365)$ & $(0.00324)$ & $(0.00193)$ & $(0.00177)$ & $(0.00426)$ & $(0.00893)$ & $(0.00191)$ & $(0.00188)$ & $(0.00140)$ & $(0.00144)$ & $(0.00171)$ & $(0.00498)$ \\
\hline \multirow[t]{2}{*}{ State } & $0.109^{*}$ & 0.0820 & -0.0726 & 0.0349 & $0.251^{*}$ & 0.153 & -0.0419 & $-0.286^{* *}$ & 0.120 & 0.107 & -0.0520 & 0.0798 \\
\hline & $(0.0634)$ & $(0.115)$ & $(0.156)$ & $(0.0835)$ & $(0.146)$ & $(0.159)$ & $(0.0783)$ & $(0.141)$ & $(0.175)$ & $(0.0971)$ & $(0.147)$ & $(0.201)$ \\
\hline
\end{tabular}


Table 3 Decomposition of the gender wage gap at selected quantiles, 2004 (Continued)

\begin{tabular}{|c|c|c|c|c|c|c|c|c|c|c|c|c|}
\hline \multirow[t]{2}{*}{ Urban } & 0.0574 & 0.146 & 0.128 & 0.0324 & -0.0359 & 0.0145 & 0.0218 & -0.0289 & 0.0235 & -0.00899 & 0.0897 & 0.0535 \\
\hline & $(0.0606)$ & $(0.145)$ & $(0.128)$ & $(0.0977)$ & $(0.0841)$ & $(0.0873)$ & $(0.0743)$ & $(0.192)$ & $(0.143)$ & (0.113) & $(0.0924)$ & (0.108) \\
\hline \multirow[t]{2}{*}{ Tbilisi } & -0.0321 & 0.0598 & 0.00196 & -0.0314 & -0.0501 & -0.0728 & 0.0618 & -0.0284 & 0.0882 & $0.143^{* *}$ & 0.0616 & 0.0345 \\
\hline & $(0.0389)$ & $(0.0786)$ & $(0.0721)$ & $(0.0566)$ & $(0.0792)$ & $(0.0780)$ & $(0.0476)$ & $(0.0973)$ & $(0.0818)$ & $(0.0670)$ & $(0.0824)$ & $(0.0912)$ \\
\hline \multirow[t]{2}{*}{ Georgian } & -0.0929 & 0.242 & -0.168 & -0.0815 & $-0.183^{*}$ & -0.125 & 0.0335 & -0.185 & 0.252 & 0.185 & 0.0258 & -0.148 \\
\hline & $(0.0808)$ & $(0.241)$ & (0.199) & $(0.122)$ & (0.0955) & $(0.146)$ & $(0.109)$ & $(0.274)$ & $(0.227)$ & $(0.141)$ & $(0.134)$ & $(0.170)$ \\
\hline \multirow[t]{2}{*}{$21-40 h^{d}$} & $-0.131^{*}$ & -0.131 & -0.188 & -0.0885 & $-0.187^{* *}$ & $-0.181^{*}$ & 0.0265 & -0.163 & 0.0161 & 0.0435 & $0.176^{*}$ & 0.127 \\
\hline & $(0.0717)$ & $(0.220)$ & $(0.196)$ & $(0.111)$ & $(0.0818)$ & $(0.0932)$ & $(0.105)$ & $(0.265)$ & $(0.219)$ & $(0.149)$ & $(0.105)$ & $(0.122)$ \\
\hline \multirow[t]{2}{*}{$40+h$} & $0.104^{* * *}$ & 0.0976 & 0.0761 & $0.144^{* *}$ & 0.0467 & 0.0240 & -0.0204 & -0.0305 & 0.0221 & -0.0151 & -0.0175 & 0.00120 \\
\hline & $(0.0374)$ & $(0.138)$ & $(0.0987)$ & $(0.0572)$ & $(0.0472)$ & $(0.0736)$ & $(0.0371)$ & $(0.0925)$ & $(0.0789)$ & (0.0534) & $(0.0544)$ & $(0.0683)$ \\
\hline \multirow[t]{2}{*}{ Seasonal hours } & $0.0132^{* *}$ & 0.0202 & $0.0196^{*}$ & 0.0131 & 0.00426 & -0.0118 & 0.00311 & 0.00366 & 0.00286 & 0.00305 & 0.00424 & 0.00780 \\
\hline & $(0.00584)$ & $(0.0164)$ & $(0.0111)$ & $(0.00954)$ & $(0.00800)$ & $(0.00908)$ & $(0.00270)$ & $(0.00582)$ & $(0.00464)$ & $(0.00382)$ & $(0.00445)$ & $(0.00522)$ \\
\hline \multirow[t]{2}{*}{ Constant } & 0.635 & 2.661 & $3.674^{*}$ & 1.589 & -0.672 & -2.256 & 0.179 & -0.894 & -2.129 & -1.056 & 1.384 & 2.888 \\
\hline & $(0.798)$ & $(1.897)$ & $(1.876)$ & $(1.241)$ & $(1.227)$ & $(2.241)$ & $(1.004)$ & $(2.152)$ & (1.988) & $(1.401)$ & $(1.573)$ & $(2.520)$ \\
\hline \multirow[t]{2}{*}{ Residual } & -0.00466 & -0.0171 & 0.0121 & 0.0159 & -0.0322 & -0.0143 & 0.00466 & 0.0181 & 0.00419 & 0.0093 & 0.0309 & -0.0109 \\
\hline & $(0.0306)$ & $(0.0471)$ & $(0.0451)$ & $(0.0481)$ & $(0.0556)$ & $(0.0703)$ & $(0.0374)$ & $(0.0531)$ & $(0.0574)$ & (0.0509) & $(0.0539)$ & $(0.0728)$ \\
\hline \multirow[t]{2}{*}{ Difference } & $0.2009^{* * *}$ & $0.1622^{*}$ & $0.2492^{* * *}$ & $0.1878^{* * *}$ & $0.2054^{* *}$ & $0.1823^{* *}$ & $0.4352^{* * *}$ & $0.2458^{* *}$ & $0.4440^{* * *}$ & $0.5054^{* * *}$ & $0.4877^{* * *}$ & $0.4474^{* * *}$ \\
\hline & $(0.0363)$ & $(0.0887)$ & $(0.0871)$ & $(0.0597)$ & (0.1019) & $(0.0817)$ & $(0.0435)$ & $(0.1064)$ & $(0.0992)$ & $(0.0714)$ & $(0.1040)$ & $(0.1139)$ \\
\hline \multirow[t]{2}{*}{ Total } & $0.6361^{* * *}$ & $0.4080^{* * *}$ & $0.6931^{* * *}$ & $0.6931^{* * *}$ & $0.6931^{* * *}$ & $0.6297^{* * *}$ & & & & & & \\
\hline & $(0.0258)$ & $(0.0758)$ & $(0.0484)$ & $(0.0491)$ & $(0.0219)$ & $(0.0922)$ & & & & & & \\
\hline
\end{tabular}

Notes: bootstrapped standard errors (200 replications, clustered by household); quarterly dummy variables included, but not reported; coefficient sums do not add up to the totals because quarterly dummies are omitted Source: GHBS data

${ }^{*} p<0.1 ; *{ }^{* *} p<0.05 ; * * * 0<0.01$

asecondary education or below is the reference group

bLow-skill blue-collar occupations are the reference group

'Agriculture is the reference group

$\mathrm{d}_{20} \mathrm{~h}$ or less is the reference group 
Table 4 Decomposition of the gender wage gap at selected quantiles, 2007

\begin{tabular}{|c|c|c|c|c|c|c|c|c|c|c|c|c|}
\hline \multirow[t]{2}{*}{ Variables } & \multicolumn{6}{|c|}{ Composition } & \multicolumn{6}{|l|}{ Structure } \\
\hline & mean & 10th & 25th & 50th & 75th & 90th & mean & 10th & 25th & 50th & 75th & 90th \\
\hline \multirow[t]{2}{*}{ Vocational $^{a}$} & -0.0269 & 0.0150 & 0.0471 & -0.0598 & -0.0475 & -0.0352 & 0.0274 & -0.0326 & -0.00857 & 0.0587 & 0.0513 & 0.0177 \\
\hline & $(0.0223)$ & $(0.0420)$ & $(0.0457)$ & $(0.0422)$ & $(0.0437)$ & $(0.0470)$ & $(0.0341)$ & $(0.0667)$ & $(0.0560)$ & $(0.0500)$ & $(0.0525)$ & $(0.0587)$ \\
\hline \multirow[t]{2}{*}{ Higher education } & -0.0692 & 0.147 & 0.0686 & -0.131 & -0.0366 & $-0.185^{*}$ & -0.144 & $-0.459^{* * *}$ & -0.214 & 0.0362 & -0.219 & -0.120 \\
\hline & (0.0599) & $(0.109)$ & $(0.118)$ & $(0.106)$ & $(0.110)$ & $(0.0987)$ & $(0.0914)$ & $(0.171)$ & $(0.153)$ & $(0.127)$ & $(0.139)$ & $(0.158)$ \\
\hline \multirow[t]{2}{*}{ Age } & -1.860 & -3.785 & -4.741 & -4.496 & 4.209 & -0.997 & $4.147^{*}$ & $6.572^{*}$ & 5.832 & 5.361 & 0.322 & 1.242 \\
\hline & $(1.762)$ & $(2.957)$ & $(3.800)$ & $(3.237)$ & (3.181) & $(2.605)$ & $(2.333)$ & (3.699) & $(4.046)$ & (3.618) & (3.855) & $(3.731)$ \\
\hline \multirow[t]{2}{*}{ Age squared } & 1.146 & 2.030 & 2.669 & 2.582 & -2.011 & 0.689 & $-2.435^{* *}$ & $-3.831^{*}$ & -3.420 & -3.014 & -0.228 & -0.815 \\
\hline & $(0.943)$ & $(1.611)$ & $(1.991)$ & $(1.701)$ & $(1.668)$ & $(1.367)$ & $(1.233)$ & (2.019) & $(2.124)$ & $(1.907)$ & $(2.020)$ & $(1.929)$ \\
\hline \multirow[t]{2}{*}{ Marriage } & -0.0147 & 0.179 & -0.104 & 0.0525 & -0.108 & 0.134 & 0.100 & -0.0421 & $0.190^{*}$ & 0.00387 & 0.0810 & -0.0383 \\
\hline & $(0.0556)$ & $(0.125)$ & $(0.114)$ & $(0.106)$ & $(0.0922)$ & $(0.0993)$ & $(0.0649)$ & $(0.129)$ & $(0.110)$ & $(0.102)$ & $(0.0965)$ & $(0.0965)$ \\
\hline \multirow[t]{2}{*}{ High-skill blue-collar ${ }^{\mathrm{b}}$} & $0.0244^{* *}$ & $0.0482^{* *}$ & $0.0524^{* * *}$ & 0.0228 & 0.00811 & -0.00778 & 0.00712 & -0.0157 & -0.00277 & 0.0134 & $0.0173^{*}$ & 0.0132 \\
\hline & $(0.0102)$ & $(0.0241)$ & $(0.0193)$ & $(0.0184)$ & $(0.0157)$ & $(0.0186)$ & $(0.00658)$ & $(0.0207)$ & $(0.0113)$ & $(0.00860)$ & $(0.0103)$ & $(0.0121)$ \\
\hline \multirow[t]{2}{*}{ Low-skill white-collar } & -0.0310 & -0.0660 & $-0.0741^{*}$ & $-0.0977^{* *}$ & 0.0229 & 0.0460 & -0.0145 & 0.0647 & -0.0265 & 0.0321 & -0.0604 & -0.0594 \\
\hline & $(0.0224)$ & $(0.0560)$ & $(0.0411)$ & $(0.0387)$ & $(0.0465)$ & $(0.0400)$ & $(0.0390)$ & $(0.0976)$ & $(0.0585)$ & $(0.0503)$ & $(0.0602)$ & $(0.0670)$ \\
\hline \multirow[t]{2}{*}{ High-skill white-collar } & -0.0732 & -0.278 & -0.0895 & -0.0549 & -0.233 & -0.0625 & 0.000817 & 0.151 & -0.232 & 0.0380 & 0.241 & 0.0263 \\
\hline & $(0.0815)$ & $(0.195)$ & $(0.137)$ & $(0.135)$ & $(0.185)$ & $(0.132)$ & $(0.120)$ & $(0.353)$ & $(0.187)$ & $(0.164)$ & $(0.203)$ & $(0.187)$ \\
\hline \multirow[t]{2}{*}{ Mining $^{c}$} & $0.00781^{* * *}$ & $0.00846^{* * *}$ & $0.00750^{* * *}$ & $0.00907^{* * *}$ & $0.00747^{*}$ & $0.0116^{*}$ & $0.000552^{* * *}$ & -0.000422 & -0.000400 & $0.000559^{* *}$ & $0.00100^{* * *}$ & $0.00159^{* * *}$ \\
\hline & $(0.00201)$ & $(0.00257)$ & $(0.00288)$ & $(0.00308)$ & $(0.00393)$ & $(0.00639)$ & $(0.000167)$ & $(0.000465)$ & $(0.000384)$ & $(0.000281)$ & $(0.000371)$ & $(0.000601)$ \\
\hline \multirow[t]{2}{*}{ Manufacturing } & $0.0225^{* *}$ & 0.0227 & 0.0264 & $0.0492^{* * *}$ & 0.000308 & -0.0158 & 0.0137 & 0.0168 & 0.0132 & 0.0127 & 0.00885 & 0.0201 \\
\hline & $(0.0101)$ & $(0.0315)$ & $(0.0261)$ & $(0.0188)$ & $(0.0167)$ & $(0.0182)$ & $(0.00908)$ & $(0.0235)$ & $(0.0178)$ & $(0.0139)$ & $(0.0139)$ & $(0.0181)$ \\
\hline \multirow[t]{2}{*}{ Utilities } & $0.00740^{*}$ & 0.00487 & 0.00480 & 0.00851 & 0.00439 & 0.00954 & $0.00390^{*}$ & 0.00275 & 0.00266 & -0.00134 & 0.00242 & $0.00921^{* *}$ \\
\hline & (0.00389) & (0.00989) & $(0.00668)$ & $(0.00582)$ & $(0.00611)$ & $(0.00794)$ & $(0.00230)$ & $(0.00421)$ & $(0.00348)$ & $(0.00324)$ & $(0.00456)$ & (0.00398) \\
\hline
\end{tabular}


Table 4 Decomposition of the gender wage gap at selected quantiles, 2007 (Continued)

\begin{tabular}{|c|c|c|c|c|c|c|c|c|c|c|c|c|}
\hline \multirow[t]{2}{*}{ Construction } & $0.0586^{* * *}$ & $0.0637^{* *}$ & $0.0602^{* *}$ & $0.0778^{* * *}$ & $0.0367^{* *}$ & $0.0367^{*}$ & 0.00127 & -0.00127 & 0.00620 & 0.000567 & -0.000519 & 0.00480 \\
\hline & $(0.0122)$ & $(0.0290)$ & $(0.0236)$ & $(0.0197)$ & $(0.0174)$ & $(0.0214)$ & $(0.00525)$ & $(0.00926)$ & $(0.00813)$ & $(0.00616)$ & $(0.00703)$ & $(0.0119)$ \\
\hline \multirow[t]{2}{*}{ Trade } & 0.0147 & -0.00465 & 0.0146 & $0.0670^{* *}$ & 0.000638 & $-0.0621^{* *}$ & 0.0476 & -0.00749 & 0.0456 & 0.0238 & 0.0675 & 0.0942 \\
\hline & $(0.0171)$ & $(0.0327)$ & $(0.0330)$ & $(0.0334)$ & $(0.0340)$ & $(0.0306)$ & $(0.0293)$ & $(0.0664)$ & $(0.0517)$ & $(0.0433)$ & $(0.0528)$ & $(0.0600)$ \\
\hline \multirow[t]{2}{*}{ Hotels and restaurants } & 0.00193 & 0.00164 & -0.00351 & 0.0127 & -0.0168 & 0.00250 & -0.00352 & -0.0106 & 0.000885 & -0.00606 & 0.000365 & -0.00883 \\
\hline & $(0.00541)$ & $(0.00899)$ & $(0.00915)$ & $(0.00967)$ & $(0.0120)$ & $(0.00884)$ & $(0.00835)$ & $(0.0154)$ & $(0.0134)$ & $(0.0127)$ & $(0.0160)$ & $(0.0155)$ \\
\hline \multirow[t]{2}{*}{ Transport } & $0.0307^{* * *}$ & $0.0563^{* *}$ & $0.0326^{*}$ & $0.0452^{* * *}$ & 0.0131 & -0.00432 & -0.00886 & -0.00812 & -0.00390 & -0.00945 & -0.0114 & -0.0110 \\
\hline & $(0.00853)$ & $(0.0226)$ & $(0.0184)$ & $(0.0134)$ & $(0.0124)$ & $(0.0131)$ & $(0.00731)$ & $(0.0127)$ & $(0.00951)$ & $(0.00776)$ & $(0.00950)$ & $(0.0188)$ \\
\hline \multirow[t]{2}{*}{ Finance } & 0.00263 & 0.00295 & 0.00875 & $0.0181^{* *}$ & -0.00321 & -0.0181 & -0.00671 & 0.00598 & 0.00282 & -0.00983 & -0.0148 & -0.0363 \\
\hline & $(0.00501)$ & $(0.00904)$ & $(0.0115)$ & $(0.00922)$ & $(0.0119)$ & $(0.0150)$ & $(0.0118)$ & $(0.0189)$ & $(0.0165)$ & $(0.0114)$ & $(0.0144)$ & $(0.0295)$ \\
\hline \multirow[t]{2}{*}{ Real estate } & 0.00784 & 0.0128 & 0.00906 & $0.0215^{*}$ & -0.00389 & -0.00546 & $0.0256^{* *}$ & 0.0218 & $0.0400^{* *}$ & 0.0212 & 0.0120 & 0.0164 \\
\hline & $(0.00575)$ & $(0.0136)$ & $(0.0129)$ & $(0.0128)$ & $(0.0173)$ & $(0.0132)$ & $(0.0113)$ & $(0.0242)$ & $(0.0184)$ & $(0.0146)$ & $(0.0195)$ & $(0.0244)$ \\
\hline \multirow[t]{2}{*}{ Public adm and defense } & $0.0483^{* * *}$ & 0.0519 & 0.0322 & $0.0756^{* * *}$ & $0.0612^{* *}$ & -0.0160 & 0.0224 & 0.0316 & 0.0323 & 0.00678 & -0.0105 & 0.0290 \\
\hline & $(0.0124)$ & $(0.0344)$ & $(0.0280)$ & $(0.0246)$ & $(0.0303)$ & $(0.0308)$ & $(0.0146)$ & $(0.0325)$ & $(0.0224)$ & $(0.0200)$ & $(0.0283)$ & $(0.0400)$ \\
\hline \multirow[t]{2}{*}{ Education } & 0.0373 & -0.0912 & -0.0465 & 0.109 & $0.161^{* *}$ & 0.0357 & $0.143^{* *}$ & 0.192 & 0.202 & 0.0772 & 0.0380 & 0.163 \\
\hline & $(0.0418)$ & $(0.0956)$ & $(0.0947)$ & $(0.0851)$ & $(0.0774)$ & $(0.0656)$ & $(0.0622)$ & $(0.177)$ & $(0.131)$ & $(0.112)$ & $(0.109)$ & $(0.111)$ \\
\hline \multirow[t]{2}{*}{ Health \& social work } & $0.0801^{* * *}$ & 0.0180 & 0.0715 & 0.0809 & $0.109^{* *}$ & $0.0963^{* *}$ & -0.00158 & 0.0688 & 0.0161 & 0.00631 & -0.0847 & -0.0544 \\
\hline & $(0.0310)$ & $(0.0570)$ & $(0.0609)$ & $(0.0528)$ & $(0.0496)$ & $(0.0446)$ & $(0.0418)$ & $(0.108)$ & $(0.0779)$ & $(0.0629)$ & $(0.0626)$ & $(0.0698)$ \\
\hline \multirow[t]{2}{*}{ Culture } & 0.00356 & -0.0105 & 0.0139 & -0.00158 & 0.00810 & 0.00259 & 0.00401 & 0.00910 & 0.00756 & 0.00818 & -0.0214 & -0.00951 \\
\hline & $(0.00616)$ & $(0.0155)$ & $(0.0150)$ & $(0.0146)$ & $(0.0148)$ & $(0.0122)$ & $(0.0105)$ & $(0.0239)$ & $(0.0206)$ & $(0.0173)$ & $(0.0203)$ & $(0.0171)$ \\
\hline \multirow[t]{2}{*}{ Private households } & 0.00631 & 0.00469 & -0.000129 & $0.0238^{*}$ & $0.0129^{*}$ & 0.00120 & $-4.35 e-05$ & -0.00394 & 0.00819 & -0.0166 & -0.0183 & 0.00818 \\
\hline & $(0.00566)$ & $(0.00759)$ & $(0.00778)$ & $(0.0135)$ & $(0.00762)$ & $(0.00531)$ & $(0.00699)$ & $(0.0134)$ & $(0.0105)$ & $(0.0139)$ & $(0.0118)$ & $(0.00811)$ \\
\hline \multirow[t]{2}{*}{ International org } & $0.00133^{*}$ & -0.000304 & 0.00130 & -0.00103 & $0.00301^{*}$ & 0.00126 & -0.00111 & 0.00443 & 0.00142 & 0.00167 & -0.00323 & -0.00531 \\
\hline & $(0.000762)$ & $(0.000767)$ & (0.000888) & $(0.00217)$ & $(0.00179)$ & $(0.000943)$ & $(0.00253)$ & $(0.00451)$ & $(0.00216)$ & $(0.00261)$ & $(0.00234)$ & $(0.00365)$ \\
\hline
\end{tabular}


Table 4 Decomposition of the gender wage gap at selected quantiles, 2007 (Continued)

\begin{tabular}{|c|c|c|c|c|c|c|c|c|c|c|c|c|}
\hline \multirow[t]{2}{*}{$\overline{\text { State }}$} & 0.0613 & 0.116 & 0.180 & 0.0852 & -0.0179 & -0.0527 & -0.0141 & -0.153 & -0.0662 & 0.0210 & 0.0447 & 0.0759 \\
\hline & $(0.0573)$ & $(0.104)$ & $(0.122)$ & $(0.106)$ & $(0.110)$ & $(0.0848)$ & $(0.0851)$ & $(0.140)$ & $(0.145)$ & $(0.125)$ & $(0.134)$ & $(0.135)$ \\
\hline \multirow[t]{2}{*}{ Urban } & 0.0319 & $0.478^{* * *}$ & 0.133 & -0.0262 & -0.136 & -0.0357 & 0.0532 & $-0.368^{*}$ & -0.0109 & 0.197 & 0.146 & 0.0982 \\
\hline & $(0.0748)$ & $(0.170)$ & $(0.193)$ & $(0.147)$ & $(0.0953)$ & $(0.103)$ & $(0.0930)$ & $(0.191)$ & $(0.204)$ & $(0.153)$ & $(0.107)$ & $(0.131)$ \\
\hline \multirow[t]{2}{*}{ Tbilisi } & $-0.0835^{*}$ & -0.0986 & -0.0198 & $-0.147^{*}$ & -0.0881 & -0.0929 & 0.0877 & $0.165^{*}$ & 0.0167 & 0.113 & 0.0801 & -0.0167 \\
\hline & $(0.0458)$ & $(0.0819)$ & $(0.0970)$ & $(0.0838)$ & $(0.0781)$ & $(0.0847)$ & $(0.0607)$ & $(0.0969)$ & $(0.106)$ & $(0.0964)$ & $(0.0915)$ & $(0.109)$ \\
\hline \multirow[t]{2}{*}{ Georgian } & 0.183 & 0.0552 & $0.427^{*}$ & $0.441^{* *}$ & 0.120 & 0.174 & -0.0439 & -0.170 & -0.210 & -0.238 & 0.0644 & 0.0226 \\
\hline & $(0.114)$ & $(0.192)$ & $(0.230)$ & $(0.212)$ & $(0.166)$ & $(0.143)$ & $(0.126)$ & $(0.218)$ & $(0.258)$ & $(0.209)$ & $(0.186)$ & $(0.179)$ \\
\hline \multirow[t]{2}{*}{$21-40$ hours $^{d}$} & $-0.0766^{*}$ & 0.0828 & -0.173 & $-0.160^{* *}$ & -0.0820 & -0.0475 & 0.0527 & -0.0533 & 0.250 & 0.108 & -0.0101 & -0.0205 \\
\hline & $(0.0442)$ & $(0.177)$ & $(0.135)$ & $(0.0747)$ & $(0.0517)$ & $(0.0534)$ & $(0.0664)$ & $(0.214)$ & $(0.161)$ & $(0.0817)$ & $(0.0651)$ & $(0.0606)$ \\
\hline \multirow[t]{2}{*}{$40+$ hours } & $0.0902^{* *}$ & $0.591^{* * *}$ & 0.131 & -0.00307 & $-0.156^{*}$ & $-0.187^{* *}$ & 0.0701 & -0.0793 & 0.202 & 0.125 & 0.0939 & 0.0705 \\
\hline & $(0.0444)$ & $(0.210)$ & $(0.118)$ & $(0.0835)$ & $(0.0927)$ & (0.0948) & $(0.0578)$ & $(0.195)$ & $(0.148)$ & $(0.0792)$ & $(0.0885)$ & $(0.0842)$ \\
\hline \multirow[t]{2}{*}{ Seasonal hours } & $0.0363^{* * *}$ & $0.0874^{* * *}$ & $0.0451^{* * *}$ & $0.0307^{* * *}$ & 0.0138 & 0.000465 & 0.00484 & 0.00408 & $0.0153^{*}$ & 0.00341 & 0.000788 & 0.000823 \\
\hline & $(0.00732)$ & $(0.0240)$ & $(0.0130)$ & (0.00978) & $(0.00851)$ & $(0.00977)$ & $(0.00341)$ & $(0.00938)$ & $(0.00842)$ & $(0.00513)$ & $(0.00473)$ & $(0.00346)$ \\
\hline \multirow[t]{2}{*}{ Constant } & 0.656 & 0.585 & 1.637 & 1.743 & -1.583 & 1.002 & $-1.885^{*}$ & -1.680 & -2.470 & -2.786 & -0.194 & -0.525 \\
\hline & $(0.824)$ & $(1.461)$ & $(1.917)$ & $(1.573)$ & $(1.566)$ & $(1.257)$ & $(1.140)$ & $(1.770)$ & $(2.020)$ & $(1.768)$ & $(1.920)$ & $(1.831)$ \\
\hline \multirow[t]{2}{*}{ Residual } & 0.0716 & -0.00996 & 0.0546 & 0.0559 & $0.130^{*}$ & 0.0816 & -0.0716 & 0.00695 & -0.0666 & -0.0786 & -0.0961 & -0.0814 \\
\hline & $(0.0591)$ & $(0.0708)$ & $(0.0897)$ & $(0.0878)$ & $(0.0727)$ & $(0.0900)$ & $(0.0612)$ & $(0.0688)$ & $(0.0895)$ & $(0.0885)$ & $(0.082)$ & $(0.0971)$ \\
\hline \multirow[t]{2}{*}{ Diff } & $0.3634^{* * *}$ & $0.3431^{* * *}$ & $0.4055^{* * *}$ & $0.3857^{* * *}$ & $0.3497^{* * *}$ & $0.3362^{* * *}$ & $0.2650^{* * *}$ & $0.3500^{* * *}$ & 0.1899 & $0.2280^{*}$ & 0.3434 & $0.1893^{*}$ \\
\hline & $(0.0451)$ & $(0.0831)$ & $(0.1111)$ & $(0.1139)$ & $(0.0850)$ & $(0.0872)$ & $(0.0497)$ & $(0.0971)$ & $(0.1208)$ & $(0.1207)$ & $(0.0984)$ & $(0.1077)$ \\
\hline \multirow[t]{2}{*}{ Total } & $0.6284^{* * *}$ & $0.6931^{* * *}$ & $0.5953^{* * *}$ & $0.6137^{* * *}$ & $0.6931^{* * *}$ & $0.5254^{* * *}$ & & & & & & \\
\hline & $(0.0275)$ & $(0.0500)$ & $(0.0583)$ & $(0.0616)$ & $(0.0488)$ & $(0.0840)$ & & & & & & \\
\hline
\end{tabular}

Notes: bootstrapped standard errors (200 replications, clustered by household); quarterly dummy variables included, but not reported; coefficient sums do not add up to the totals because quarterly dummies are omitted; ${ }^{* * *} p<0.01,{ }^{* *} p<0.05,{ }^{*} p<0.1{ }^{;}$secondary education or below is the reference group; ${ }^{b}$ low-skill blue-collar occupations is the reference group; ${ }^{c}$ agriculture is the reference group; ${ }^{d} 20$ hours or less is the reference group

Source: GHBS data 
the gender wage gap was $0.41 \log$ points at the 10 th percentile and $0.63 \log$ points at the 90th percentile, by 2007 , the gap increased to $0.69 \log$ points at the 10th percentile and decreased to $0.53 \mathrm{log}$ points at the 90th percentile.

The increase in the lower part of the distribution can in part be attributed to the expansion of the construction and transport industries, which lifted the proportion of high-skilled blue-collar male workers between 2004 and 2007. ${ }^{12}$ Indeed, the contribution of construction alone doubled at the 25th percentile from $0.03 \log$ points to 0.06 $\log$ points. In a related development, not visible in the analysis of the gap at the mean, men at the bottom of the distribution became more concentrated in urban areas, raising the gap at the 10th percentile by 0.48 log points, potentially because construction projects took place mostly in urban areas. We note, however, that women's urban premium was higher than men's at the bottom of the distribution, indicating that women benefited more from working in urban areas than men. Also explaining the increase in the gap at the bottom of the distribution, the high concentration of women in education, health and social services, and culture, and in white-collar occupations, which lowered the gap at the bottom of the distribution in 2004, no longer decreased it in a statistically significant way in 2007 . This was likely because the growing wages in these industries moved many women into higher percentiles. In contrast, sociodemographic shifts placed downward pressure on the gender wage gap at the bottom of the distribution although not strongly enough to outweigh the upward forces. For example, the contribution of marriage to the gender wage gap decreased at the bottom of the distribution. This was in part because, as the working age population became younger, there were more single male and female workers. However, the increase in the proportion of single male wage workers was stronger at the bottom of the distribution. At the top, similar shares of high-income men and women were married, suggesting that for women with the potential to earn high wages marriage may not present a problem for entering the labor market.

The decrease at the top of the distribution compared to 2004 was in part due to the increased presence of women with higher education among high-earning individuals, lowering the gap at the 90th percentile by $0.19 \log$ points. Furthermore, the growth in state sector wages relative to the private sector partially explains why gender differences in the state sector no longer raised the gap at the 75th percentile in 2007, as they did in 2004. More generally, the faster growth of women's wages in sectors, such as hotels and restaurants, transport, and public administration and defense, closed the gender gap in the sectoral premia, contributing to the reduction in the middle and upper parts of the wage distribution. ${ }^{13}$ Additionally, women's working hours increased, moving many of them into higher income quantiles compared to 2004. For instance, the proportions of women working $40 \mathrm{~h}$ or more overtook their male counterparts at the 75th and 90th percentiles decreasing the gap 0.16 and 0.19 log points, respectively. We note that men working full time and in seasonal employment were concentrated at the bottom of the distribution, contributing to raising the gap at the bottom. This finding highlights the heterogeneity in the role of full-time work for men and women: at the bottom of the distribution, proportionately more men than women are full-time workers whereas at the top of the distribution, these proportions are reversed.

The analysis of the unexplained portion of the gap sheds further light on the shape of the gender wage gap distribution and on the changes in it. Indeed, in 2004, the joint 
contribution of the explanatory factors was relatively uniform across the distribution, implying that the upward slope of the gender wage gap was due to unexplained factors in the form of the lower returns to characteristics among women at the top of the distribution. This prompts us to speculate about the presence of a glass ceiling effect in 2004 that limited women's opportunities for advancement. On the one hand, some factors played a role that ran contrary to the glass ceiling effect. For example, men's industrial premia were lower at the top of the wage distribution, as was men's premium to higher education. In fact, women at the top of the distribution had greater returns to higher education than men. However, other factors were more supportive of it. For example, women faced a sizable marriage penalty at the top of the distribution (this becomes particularly obvious in 2005 and $2006^{14}$ ) even though, as we have established, similar proportions of high-earning men and women were married. In contrast, at the bottom of the distribution, women's marriage premium was higher than men's. These findings suggest that at the bottom of the wage distribution marriage served as a barrier to female employment (given that proportionately fewer employed women than employed men were married) whereas at the top of the wage distribution it served as a barrier to earning higher wages, in line with the glass ceiling effect. By 2007, the evidence of the glass ceiling effect is weaker. This may be because the glass ceiling effect is not as strong in the state sector, whose share in the upper percentiles of the distribution increased due the growth in state sector wages. The increase in state sector wages may also explain why the wage premium that married women held at the bottom of the distribution disappeared.

\subsection{After the recession}

The 2008 recession had a considerable impact on the Georgian economy and on the gender wage gap, in particular. The gap at the mean shrank from $0.63 \mathrm{log}$ points in 2007 to $0.44 \log$ points in 2011 (Tables 4 and 5). This happened even though industrial segregation in some sectors of the economy became stronger and widened the gap. For example, the contribution of the gender differences in employment in construction, transport, and public administration and defense increased from $0.14 \log$ points in 2007 to $0.27 \log$ points in 2011, as the presence of men in these sectors, except for construction, increased relative to women. This development was associated with the different speed with which the recession hit these sectors. For example, the analysis of the intermediate years reveals that the contribution of the construction sector in raising the gap reached its peak in 2008, followed by a post-recessionary decline and then an uptick in 2011. On the other hand, the contribution of the transport sector reached its peak in 2009 before declining to $0.04 \log$ points in 2010 and staying there in 2011. The contribution of public administration and defense also peaked in 2009 at $0.13 \log$ points before dropping to $0.10 \log$ points in 2010 due to the recession-induced public sector cuts and staying there in 2011.

These changes in sectoral patterns jointly widened the gap. However, overall, the contracting pressure dominated. For example, the recessionary contraction in construction prompted the reduction in the proportion of high-skilled blue-collar male workers, rendering its role at widening the gap statistically insignificant. Moreover, a higher proportion of women with higher education decreased the mean gap by $0.18 \log$ points in 2011. Both effects were the strongest at the bottom 
Table 5 Decomposition of the gender wage gap at selected quantiles, 2011

\begin{tabular}{|c|c|c|c|c|c|c|c|c|c|c|c|c|}
\hline \multirow[t]{2}{*}{ Variables } & \multicolumn{6}{|c|}{ Composition } & \multicolumn{6}{|l|}{ Structure } \\
\hline & $\overline{\text { mean }}$ & 10th & 25th & 50th & 75th & 90th & $\overline{\text { mean }}$ & 10th & 25th & 50th & 75th & 90th \\
\hline \multirow[t]{2}{*}{ Vocational $^{a}$} & 0.0147 & -0.0348 & -0.0355 & -0.0220 & $0.105^{* *}$ & $0.0770^{*}$ & -0.0281 & -0.0448 & 0.0110 & 0.0212 & $-0.106^{* *}$ & -0.0811 \\
\hline & $(0.0271)$ & $(0.114)$ & $(0.0264)$ & $(0.0366)$ & $(0.0429)$ & $(0.0424)$ & (0.0339) & $(0.125)$ & $(0.0410)$ & $(0.0450)$ & $(0.0453)$ & $(0.0524)$ \\
\hline \multirow[t]{2}{*}{ Higher education } & $-0.180^{* *}$ & $-0.701^{*}$ & -0.103 & -0.0928 & 0.0749 & 0.114 & 0.0797 & 0.628 & 0.00889 & -0.00216 & -0.155 & $-0.262^{*}$ \\
\hline & $(0.0851)$ & $(0.380)$ & $(0.0715)$ & $(0.0834)$ & $(0.0971)$ & $(0.112)$ & $(0.101)$ & $(0.403)$ & $(0.108)$ & $(0.108)$ & $(0.103)$ & $(0.141)$ \\
\hline \multirow[t]{2}{*}{ Age } & 1.827 & 2.455 & -2.321 & 1.316 & -0.133 & 2.069 & -0.914 & 2.882 & 3.613 & -2.856 & -0.667 & -1.532 \\
\hline & $(1.579)$ & $(5.560)$ & $(2.335)$ & $(2.307)$ & $(2.544)$ & $(2.480)$ & $(2.050)$ & $(5.708)$ & $(2.620)$ & $(2.686)$ & (2.999) & $(4.209)$ \\
\hline \multirow[t]{2}{*}{ Age squared } & -0.744 & -1.354 & 1.320 & -0.564 & 0.391 & -0.770 & 0.306 & -1.537 & -1.926 & 1.302 & 0.0792 & 0.486 \\
\hline & $(0.796)$ & $(2.779)$ & $(1.167)$ & $(1.188)$ & $(1.322)$ & $(1.301)$ & $(1.052)$ & $(2.875)$ & $(1.350)$ & $(1.403)$ & $(1.578)$ & $(2.185)$ \\
\hline \multirow[t]{2}{*}{ Marriage } & -0.0837 & -0.0822 & -0.0692 & -0.0910 & 0.0351 & -0.0201 & $0.157^{*}$ & 0.176 & 0.0801 & $0.219^{* *}$ & -0.0147 & 0.152 \\
\hline & $(0.0676)$ & $(0.189)$ & $(0.0769)$ & $(0.0858)$ & $(0.0959)$ & $(0.0796)$ & $(0.0845)$ & $(0.174)$ & $(0.0829)$ & $(0.0963)$ & $(0.101)$ & $(0.128)$ \\
\hline \multirow[t]{2}{*}{ High-skill blue-collar ${ }^{b}$} & 0.00825 & 0.0172 & 0.0163 & 0.0106 & -0.00537 & 0.00937 & 0.00207 & -0.00549 & -0.00555 & 0.00650 & 0.00339 & 0.00408 \\
\hline & $(0.00649)$ & $(0.0247)$ & $(0.0114)$ & $(0.00980)$ & $(0.00904)$ & $(0.00910)$ & $(0.00567)$ & $(0.0173)$ & $(0.00842)$ & $(0.00810)$ & $(0.00611)$ & $(0.00832)$ \\
\hline \multirow[t]{2}{*}{ Low-skill white-collar } & 0.0196 & 0.0366 & 0.00914 & 0.0212 & 0.00377 & 0.0172 & -0.0550 & -0.0614 & -0.0707 & -0.0686 & -0.0542 & -0.0113 \\
\hline & $(0.0264)$ & $(0.0859)$ & $(0.0274)$ & $(0.0393)$ & $(0.0421)$ & $(0.0529)$ & $(0.0391)$ & $(0.108)$ & $(0.0478)$ & $(0.0489)$ & $(0.0486)$ & $(0.0650)$ \\
\hline \multirow[t]{2}{*}{ High-skill white-collar } & 0.0423 & 0.188 & 0.108 & 0.0632 & $-0.215^{* *}$ & $-0.161^{*}$ & -0.136 & -0.310 & $-0.268^{* *}$ & -0.120 & 0.178 & 0.0177 \\
\hline & $(0.0775)$ & $(0.205)$ & $(0.0702)$ & $(0.120)$ & $(0.0955)$ & $(0.0937)$ & $(0.105)$ & $(0.258)$ & $(0.117)$ & $(0.151)$ & $(0.109)$ & $(0.162)$ \\
\hline \multirow[t]{2}{*}{ Mining $^{c}$} & $0.0340^{* * *}$ & $0.0762^{* * *}$ & $0.0465^{* * *}$ & $0.0344^{* * *}$ & $0.0171^{* * *}$ & $-0.00882^{*}$ & 0.000626 & 0.00396 & -0.00321 & -0.00171 & 0.00193 & 0.00359 \\
\hline & (0.00399) & $(0.0189)$ & $(0.00642)$ & $(0.00546)$ & $(0.00622)$ & $(0.00490)$ & $(0.00156)$ & $(0.00481)$ & $(0.00207)$ & $(0.00259)$ & $(0.00246)$ & $(0.00300)$ \\
\hline \multirow[t]{2}{*}{ Manufacturing } & 0.0139 & 0.0818 & $0.0487^{* * *}$ & 0.00945 & -0.0118 & -0.0109 & 0.0191 & 0.0527 & -0.0278 & 0.00602 & 0.0117 & 0.0309 \\
\hline & $(0.00979)$ & $(0.0580)$ & $(0.0171)$ & $(0.0141)$ & $(0.0168)$ & $(0.0126)$ & $(0.0155)$ & $(0.0598)$ & $(0.0184)$ & $(0.0166)$ & $(0.0194)$ & $(0.0217)$ \\
\hline \multirow[t]{2}{*}{ Utilities } & $0.0282^{* * *}$ & $0.0938^{* * *}$ & $0.0454^{* * *}$ & $0.0271^{* * *}$ & -0.00568 & -0.0112 & -0.000485 & 0.00164 & -0.00363 & 0.000740 & -0.00253 & -0.00902 \\
\hline & $(0.00594)$ & $(0.0261)$ & $(0.00915)$ & $(0.00755)$ & $(0.00661)$ & $(0.00748)$ & $(0.00255)$ & $(0.00738)$ & $(0.00294)$ & $(0.00314)$ & $(0.00360)$ & $(0.00903)$ \\
\hline
\end{tabular}


Table 5 Decomposition of the gender wage gap at selected quantiles, 2011 (Continued)

\begin{tabular}{|c|c|c|c|c|c|c|c|c|c|c|c|c|}
\hline \multirow[t]{2}{*}{ Construction } & $0.0710^{* * *}$ & $0.213^{* * *}$ & $0.0909^{* * *}$ & $0.0506^{* * *}$ & 0.00938 & -0.00316 & 0.00265 & 0.00444 & 0.00196 & 0.000663 & 0.00237 & -0.00546 \\
\hline & $(0.0105)$ & $(0.0477)$ & $(0.0170)$ & $(0.0114)$ & $(0.00996)$ & $(0.0112)$ & $(0.00220)$ & $(0.00547)$ & $(0.00248)$ & $(0.00193)$ & $(0.00240)$ & $(0.00803)$ \\
\hline \multirow[t]{2}{*}{ Trade } & -0.0214 & 0.0778 & $0.0460^{*}$ & $-0.0489^{* *}$ & -0.0321 & $-0.0578^{*}$ & $0.0658^{* *}$ & 0.0814 & 0.00141 & $0.0613^{* *}$ & 0.0479 & $0.0934^{* *}$ \\
\hline & $(0.0162)$ & $(0.0807)$ & $(0.0260)$ & $(0.0238)$ & $(0.0308)$ & $(0.0328)$ & $(0.0258)$ & $(0.0937)$ & $(0.0321)$ & $(0.0288)$ & $(0.0350)$ & $(0.0450)$ \\
\hline \multirow[t]{2}{*}{ Hotels and restaurants } & $-0.0152^{* *}$ & -0.0223 & -0.00809 & -0.00747 & -0.00901 & -0.00960 & 0.0119 & 0.0203 & 0.00429 & 0.00900 & 0.0117 & 0.0165 \\
\hline & $(0.00677)$ & $(0.0227)$ & $(0.00620)$ & $(0.00706)$ & $(0.0123)$ & $(0.00971)$ & (0.00939) & $(0.0270)$ & $(0.0111)$ & $(0.0113)$ & $(0.0144)$ & $(0.0119)$ \\
\hline \multirow[t]{2}{*}{ Transport } & $0.0358^{* * *}$ & $0.105^{* * *}$ & $0.0701^{* * *}$ & $0.0282^{* *}$ & -0.0137 & -0.00811 & 0.00958 & 0.0197 & -0.00272 & $0.0175^{*}$ & $0.0173^{*}$ & -0.0279 \\
\hline & $(0.00850)$ & $(0.0376)$ & $(0.0151)$ & $(0.0125)$ & $(0.0109)$ & $(0.0108)$ & (0.00789) & $(0.0236)$ & $(0.00878)$ & $(0.00908)$ & $(0.00985)$ & $(0.0204)$ \\
\hline \multirow[t]{2}{*}{ Finance } & $0.0103^{* *}$ & $0.0431^{* * *}$ & $0.0205^{* * *}$ & -0.000687 & 0.00177 & 0.00161 & 0.00223 & 0.0201 & 0.00810 & 0.00632 & -0.00265 & -0.0114 \\
\hline & $(0.00402)$ & $(0.0149)$ & $(0.00706)$ & $(0.00757)$ & $(0.00712)$ & $(0.0107)$ & $(0.00668)$ & $(0.0166)$ & $(0.00677)$ & $(0.00616)$ & $(0.00872)$ & $(0.0134)$ \\
\hline \multirow[t]{2}{*}{ Real estate } & $0.0123^{* * *}$ & $0.0641^{* * *}$ & $0.0237^{* * *}$ & 0.00126 & 0.000269 & -0.00478 & $0.0116^{* *}$ & 0.0229 & 0.00739 & 0.00848 & 0.00542 & 0.0208 \\
\hline & $(0.00419)$ & $(0.0207)$ & $(0.00885)$ & $(0.00674)$ & $(0.00626)$ & $(0.00688)$ & $(0.00562)$ & $(0.0158)$ & $(0.00645)$ & $(0.00628)$ & $(0.00818)$ & $(0.0127)$ \\
\hline \multirow[t]{2}{*}{ Public adm and defense } & $0.0967^{* * *}$ & $0.225^{* *}$ & $0.142^{* * *}$ & $0.133^{* * *}$ & $0.0843^{* * *}$ & 0.00274 & 0.0164 & 0.0675 & 0.00165 & 0.0114 & 0.00743 & $-0.0860^{*}$ \\
\hline & $(0.0185)$ & $(0.0876)$ & $(0.0336)$ & $(0.0299)$ & $(0.0306)$ & $(0.0388)$ & $(0.0208)$ & $(0.0680)$ & $(0.0251)$ & $(0.0269)$ & $(0.0314)$ & $(0.0441)$ \\
\hline \multirow[t]{2}{*}{ Education } & -0.0565 & -0.234 & -0.0695 & 0.00307 & 0.143 & $0.162^{* *}$ & 0.0181 & 0.160 & 0.00605 & -0.0265 & -0.136 & -0.0985 \\
\hline & $(0.0544)$ & $(0.209)$ & $(0.0497)$ & $(0.0689)$ & $(0.100)$ & $(0.0695)$ & $(0.0720)$ & $(0.245)$ & $(0.0845)$ & $(0.0863)$ & $(0.108)$ & $(0.113)$ \\
\hline \multirow[t]{2}{*}{ Health and social work } & -0.0337 & -0.0733 & -0.0236 & -0.0355 & 0.00915 & 0.0406 & 0.0281 & 0.0603 & -0.00893 & 0.0245 & -0.00744 & 0.0374 \\
\hline & $(0.0245)$ & $(0.0914)$ & $(0.0242)$ & $(0.0316)$ & $(0.0371)$ & $(0.0320)$ & $(0.0304)$ & $(0.106)$ & $(0.0370)$ & $(0.0374)$ & $(0.0405)$ & $(0.0532)$ \\
\hline \multirow[t]{2}{*}{ Culture } & $-0.0196^{*}$ & -0.0260 & -0.00651 & -0.0146 & 0.00302 & -0.0111 & $0.0327^{*}$ & 0.0817 & 0.0212 & 0.0221 & 0.00165 & 0.0257 \\
\hline & $(0.0118)$ & $(0.0528)$ & $(0.0121)$ & $(0.0174)$ & $(0.0196)$ & $(0.0187)$ & $(0.0169)$ & $(0.0593)$ & $(0.0198)$ & $(0.0224)$ & $(0.0232)$ & $(0.0296)$ \\
\hline \multirow[t]{2}{*}{ Private households } & -0.0215 & -0.0151 & -0.0163 & $-0.0228^{* *}$ & -0.0304 & 0.00925 & 0.0189 & 0.00907 & 0.00578 & 0.0201 & 0.0275 & 0.0177 \\
\hline & $(0.0141)$ & $(0.0474)$ & $(0.0110)$ & $(0.0112)$ & $(0.0198)$ & $(0.00634)$ & $(0.0172)$ & $(0.0539)$ & $(0.0156)$ & $(0.0143)$ & $(0.0209)$ & $(0.0128)$ \\
\hline \multirow[t]{2}{*}{ International org } & $-0.00222^{*}$ & 0.000846 & 0.000317 & $-0.00130^{*}$ & -0.00362 & -0.00574 & 0.00128 & 0.000513 & 0.00103 & 0.00195 & 0.00361 & $9.75 e-06$ \\
\hline & $(0.00116)$ & $(0.00186)$ & $(0.000814)$ & $(0.000765)$ & $(0.00283)$ & $(0.00409)$ & $(0.00223)$ & $(0.00234)$ & $(0.00168)$ & $(0.00173)$ & $(0.00402)$ & $(0.00711)$ \\
\hline
\end{tabular}


Table 5 Decomposition of the gender wage gap at selected quantiles, 2011 (Continued)

\begin{tabular}{|c|c|c|c|c|c|c|c|c|c|c|c|c|}
\hline \multirow[t]{2}{*}{ State } & 0.0399 & 0.167 & 0.0618 & -0.0296 & -0.0703 & -0.153 & -0.0431 & -0.0883 & -0.104 & -0.0381 & 0.0784 & $0.246^{*}$ \\
\hline & $(0.0656)$ & $(0.132)$ & $(0.0512)$ & $(0.0907)$ & $(0.112)$ & (0.113) & $(0.0787)$ & $(0.145)$ & $(0.0671)$ & $(0.108)$ & $(0.126)$ & $(0.141)$ \\
\hline \multirow[t]{2}{*}{ Urban } & 0.104 & 0.317 & 0.00973 & 0.0426 & 0.00949 & $-0.163^{* *}$ & -0.0796 & -0.110 & 0.0358 & 0.0151 & 0.0197 & 0.0428 \\
\hline & $(0.136)$ & $(0.483)$ & (0.0918) & $(0.0964)$ & (0.0938) & $(0.0813)$ & $(0.151)$ & $(0.517)$ & $(0.0995)$ & $(0.109)$ & $(0.106)$ & $(0.114)$ \\
\hline \multirow[t]{2}{*}{ Tbilisi } & -0.0116 & -0.129 & 0.0486 & 0.0280 & 0.0267 & 0.0194 & -0.0470 & 0.0628 & -0.0798 & $-0.102^{*}$ & -0.00123 & $-0.195^{*}$ \\
\hline & $(0.0455)$ & $(0.110)$ & $(0.0418)$ & $(0.0495)$ & $(0.0607)$ & $(0.0736)$ & $(0.0551)$ & $(0.113)$ & $(0.0497)$ & $(0.0616)$ & $(0.0696)$ & $(0.106)$ \\
\hline \multirow[t]{2}{*}{ Georgian } & 0.130 & 0.183 & -0.0426 & 0.0397 & 0.318 & 0.239 & -0.113 & -0.369 & 0.00992 & 0.0930 & -0.158 & -0.201 \\
\hline & $(0.110)$ & $(0.387)$ & $(0.122)$ & $(0.174)$ & $(0.210)$ & $(0.206)$ & $(0.135)$ & $(0.391)$ & $(0.139)$ & $(0.171)$ & $(0.219)$ & $(0.247)$ \\
\hline \multirow[t]{2}{*}{$21-40$ hours $^{d}$} & -0.0636 & -0.0124 & 0.0580 & 0.123 & $-0.125^{*}$ & -0.0453 & 0.135 & $0.636^{*}$ & 0.0935 & -0.0841 & 0.0760 & -0.0959 \\
\hline & $(0.0905)$ & $(0.389)$ & $(0.0710)$ & $(0.0777)$ & $(0.0646)$ & $(0.0506)$ & $(0.110)$ & $(0.374)$ & $(0.0978)$ & $(0.0846)$ & $(0.0779)$ & $(0.0841)$ \\
\hline \multirow[t]{2}{*}{$40+$ hours } & 0.0650 & 0.358 & $0.193^{* * *}$ & $0.189^{* * *}$ & -0.0736 & -0.00686 & 0.0769 & $0.448^{*}$ & 0.0219 & -0.0710 & 0.0786 & -0.0873 \\
\hline & $(0.0593)$ & $(0.324)$ & $(0.0624)$ & $(0.0596)$ & $(0.0583)$ & $(0.0517)$ & $(0.0714)$ & $(0.254)$ & $(0.0633)$ & $(0.0572)$ & $(0.0624)$ & $(0.0769)$ \\
\hline \multirow[t]{2}{*}{ Seasonal hours } & $0.0182^{* * *}$ & $0.0734^{* *}$ & $0.0280^{* * *}$ & $0.0266^{* * *}$ & 0.00139 & 0.00309 & 0.00274 & 0.00299 & -0.00123 & -0.00879 & -0.00305 & -0.00567 \\
\hline & $(0.00662)$ & $(0.0354)$ & $(0.01000)$ & $(0.00738)$ & $(0.00729)$ & $(0.00626)$ & $(0.00724)$ & $(0.0267)$ & $(0.00666)$ & $(0.00598)$ & $(0.00721)$ & $(0.00741)$ \\
\hline \multirow[t]{2}{*}{ Constant } & $-1.277^{*}$ & -2.088 & 0.135 & -1.086 & -0.465 & -1.321 & 0.750 & -2.749 & -1.107 & 1.916 & 1.232 & 1.879 \\
\hline & $(0.757)$ & (2.985) & $(1.240)$ & $(1.090)$ & $(1.236)$ & (1.197) & $(0.965)$ & $(2.870)$ & $(1.284)$ & (1.306) & $(1.433)$ & $(2.037)$ \\
\hline \multirow[t]{2}{*}{ Residual } & 0.0155 & 0.0179 & 0.00151 & 0.0563 & 0.0124 & 0.0666 & -0.0155 & 0.0135 & -0.0441 & -0.0689 & -0.0316 & -0.0454 \\
\hline & $(0.0501)$ & $(0.132)$ & $(0.0476)$ & $(0.041)$ & $(0.0649)$ & $(0.0474)$ & $(0.0538)$ & $(0.114)$ & $(0.0439)$ & $(0.045)$ & $(0.0621)$ & $(0.0639)$ \\
\hline \multirow[t]{2}{*}{ Diff } & $0.2203^{* * *}$ & 0.2846 & 0.0337 & $0.2877^{* * *}$ & $0.2074^{* * *}$ & $0.1691^{* * *}$ & $0.2227^{* * *}$ & 0.0375 & $0.2877^{* * *}$ & $0.2400^{* * *}$ & $0.4425^{* * *}$ & $0.1792^{* *}$ \\
\hline & $(0.0671)$ & $(0.1886$ & $(0.0542)$ & $(0.0723)$ & $(0.0640)$ & $(0.0554)$ & $(0.0735)$ & $(0.1957)$ & $(0.0255)$ & $(0.0836)$ & $(0.0851)$ & $(0.0877)$ \\
\hline \multirow[t]{2}{*}{ Total } & $0.4431^{* * *}$ & $0.3221^{* * *}$ & $0.3213^{* * *}$ & $0.5276^{* * *}$ & $0.6498^{* * *}$ & $0.3483^{* * *}$ & & & & & & \\
\hline & $(0.0252)$ & $(0.1074$ & $(0.0585)$ & $(0.0695)$ & $(0.0489)$ & $(0.0856)$ & & & & & & \\
\hline
\end{tabular}

Notes: bootstrapped standard errors (200 replications, clustered by household); quarterly dummy variables included, but not reported; coefficient sums do not add up to the totals because quarterly dummies are omitted; ${ }^{* * *} p<0.01,{ }^{* *} p<0.05,{ }^{*} p<0.1{ }^{;}{ }^{a}$ secondary education or below is the reference group; ${ }^{b}$ low-skill blue-collar occupations is the reference group; ${ }^{c}$ agriculture is the reference group; ${ }^{d} 20$ hours or less is the reference group

Source: GHBS data 
of the distribution, contributing to the reduction in the gender wage gap among low-earning individuals. The latter development may indicate that after the recession proportionately more women with higher education remained or became employed in low-paid positions. It is notable that at the top of the distribution, women's returns to higher education remained above men's returns, similar to the pre-recessionary years. These findings hint at the presence of the female addedworker effect at the bottom of the distribution due to the recession, spurred by well-educated women accepting lowly remunerated jobs in response to spousal job loss (Khitarishvili 2013).

In total, the gap at the 10th percentile more than halved from 0.69 log points in 2007 to $0.32 \log$ points in 2011. It also sharply contracted at the 90th percentile, from 0.53 $\log$ points in 2004 to $0.35 \mathrm{log}$ points in 2011. Such a decrease at the top of the distribution was also due to a number of factors. For example, although the work hours decreased for both men and women, the drop was stronger for men at the top of the distribution, resulting in the reduction in the gender wage gap at the 90th percentile. We note, however, that similar to the 2004-2007 period, at the bottom of the distribution, proportionately more men than women are engaged in full-time and seasonal work, once again underscoring gender differences in the working hours of low- and high-earning workers. We also find that, even though the proportion of wage workers in urban areas declined for both men and women, the decrease was stronger for highearning men, which further contributed to the reduction in the gap at the top of the distribution. Finally, female workers engaged in high-skill white-collar occupations were over-represented compared to male workers among high-earning individuals, shrinking the gap.

In contrast to the top and the bottom of the distribution, the contraction at the median was much more modest from 0.61 to $0.53 \log$ points between 2007 and 2011 . As a result, the distribution of the gender wage gap in 2011 took on an inverted-U shape, underscoring that the gender wage gap is the highest in the middle of the distribution. Despite the reduction in the gender wage gap all across the wage distribution between 2004 and 2011, it remained sizable.

Our analysis has established the important role of explanatory factors in contributing to changes in the distribution of the gender wage gap. However, it has also revealed the considerable role of unobservable factors, despite the apparent reduction in their importance. The unexplained portion of the gap at the mean was about $68 \%$ of the overall gap in 2004, $42 \%$ in 2007, and $50 \%$ in 2011 (Tables 3, 4, and 5). Additionally, in 2004 , its role proportionately increased from $60 \%$ of the gap at the 10th percentile to $71 \%$ of the gap at the 90th percentile, lending further support to the hypothesis of the glass ceiling effect. The large magnitude of the unexplained portion of the gap may be attributed to a range of factors. Job flexibility (Winder 2009) and the amount of leave time mothers take after giving birth (Dechter 2014) likely play a strong role. Recent studies also underscore the role of household responsibilities in contributing to the presence of the gender wage gap by constraining women's engagement in labor markets (Maani and Cruickshank 2010). Arguably, employer discrimination can be an important factor contributing to the large unexplained portion of the gap (Pitts et al. 2014). The examination of these questions in the Georgian context merits careful investigation in future work. 


\section{3 Ñopo (2008) decomposition results}

In this section, we report the results of the statistical matching decomposition technique developed in Nopo (2008) to assess the extent to which the FFL results may be influenced by the lack of overlap in the supports of male and female characteristics. We compare the Nopo results with the FFL results at the mean for the whole period 2004-2011 and for 2004, 2007, and 2011 separately.

There is indeed evidence of the lack of overlap. The matching rate using the pooled 2004-2011 dataset and the full set of variables ${ }^{15}$ is below $70 \%$ and is higher for women than men at 69.9 and $57 \%$, respectively (Table 6). This finding is consistent with women specializing in only a handful of industries and men being more spread out across industries. We note that the matching rates are much smaller when considering individual years.

Based on the findings from the 2004-2011 period, the explained portion of the gap of $0.24 \log$ points using the FFL approach is below its Nopo approach counterpart of $0.27 \log$ points defined over the shared support. In other words, the net impact of ignoring the lack of overlap in supports is negative. This is because, on the one hand, the differences between matched and unmatched women's characteristics widen the gender wage gap by $0.07 \log$ points. This result suggests that women, whose characteristics could not be matched to men's, earn less than women, whose characteristics were matched. The culprits are the relatively lowly remunerated health and social services, culture, and education sectors, in particular, pre-school and primary school teachers, who are almost exclusively female. The role of the differences in the matched and unmatched women's wages grew between 2004 and 2011. ${ }^{16}$ Whereas in 2004, unmatched women earned only slightly less than matched women, by 2007 and 2011, this difference had grown to 0.17 log points.

Outweighing this effect, the differences between matched and unmatched men's characteristics contracted the gender wage gap during 2004-2011 by $0.06 \log$ points. This finding reveals that men, whose characteristics could not be matched with women's, earn less than men, whose characteristics were matched. One of the main

Table 6 Comparison of the decomposition results based on Ñopo (2008) and Firpo et al. (2007), expressed in log points

\begin{tabular}{|c|c|c|c|c|c|c|c|c|}
\hline & \multicolumn{4}{|l|}{ Ñopo (2008) } & \multicolumn{4}{|c|}{ Firpo et al. (2007) } \\
\hline & $2004-2011$ & 2004 & 2007 & 2011 & 2004-2011 & 2004 & 2007 & 2011 \\
\hline$\Delta$ & 0.5925 & 0.6361 & 0.6284 & 0.4431 & 0.5925 & 0.6361 & 0.6284 & 0.4431 \\
\hline$\Delta_{\circ}$ & 0.3155 & 0.2802 & 0.2992 & 0.2628 & 0.3524 & 0.4352 & 0.2650 & 0.2227 \\
\hline$\Delta_{\mathrm{f}}$ & 0.0662 & 0.0312 & 0.1761 & 0.1701 & & & & \\
\hline$\Delta_{\mathrm{m}}$ & -0.0561 & 0.1196 & -0.1020 & -0.0906 & & & & \\
\hline$\Delta_{\mathrm{x}}$ & 0.2668 & 0.2050 & 0.2552 & 0.1007 & 0.2401 & 0.2009 & 0.3634 & 0.2203 \\
\hline$\Delta_{\mathrm{f}}+\Delta_{\mathrm{m}}$ & 0.0101 & 0.1508 & 0.0741 & 0.0795 & & & & \\
\hline Percent F & 0.6992 & 0.4139 & 0.3279 & 0.3503 & & & & \\
\hline Percent M & 0.5664 & 0.2912 & 0.2162 & 0.2805 & & & & \\
\hline
\end{tabular}

Notes: the total gap $\Delta$ is $\Delta_{\mathrm{x}}+\Delta_{\mathrm{m}}+\Delta_{\mathrm{f}}+\Delta_{\mathrm{o}}$; $\Delta \mathrm{o}$ is the wage structure effect and $\Delta \mathrm{x}$ is the endowment effect, defined over the common support in the case of Ñopo (2008); $\Delta_{m}\left(\Delta_{f}\right)$ is the contribution of the differences in the characteristics of males (females) who were matched to female (male) characteristics and those who were not matched with female (male) characteristics; percent $M$ is the percentage of males that were matched to females; percent $F$ is the percentage of females that were matched to males; the set of variables used in the Nopo and the FFL estimations are age and dummy variables for education, marriage, urban residence, Tbilisi, Georgian, skills, industry, state, and working hours Source: GHBS data 
reasons is that men are much more likely to work in blue-collar occupations than women. For example, the vast majority of unmatched men in the construction industry work in lower-paying blue-collar construction jobs. The men in the construction industry, who are matched with women, work primarily in high-skilled white-collar occupations, such as accounting and support personnel, in which women are well-represented. This explains why the wages of the unmatched men are lower even though the wages in the construction industry are above average in Georgia. The role of the wage differences between matched and unmatched men grew at reducing the gap between 2004 and 2011. In fact, in 2004, unmatched men earned more than their matched counterparts. But in 2007 and 2011, unmatched men earned less. This likely happened due to the growth in low-skilled jobs for men in the expanding construction sector and the increase in high-skilled jobs in construction, for which there were matches among women.

The results for individual years suggest that between 2004 and 2011 these developments resulted in the decline in the bias in the explained portion of the gap.

Moving to the analysis of the unexplained portion, at $0.35 \log$ points, the FFL approach yields a slightly higher estimate than the $0.32 \log$ points using the approach in Nopo (2008). In individual years, in 2007 and 2011, in particular, the estimates of the unexplained portion of the gap using the FFL and Nopo approaches are very close.

In sum, our analysis finds evidence of the lack of overlap in men's and women's characteristics in Georgia and provides useful insights into the implications of ignoring it. However, the magnitude of the bias appears to be relatively small during 2004-2011, declining when individual years are considered separately. This is a finding consistent with other studies (Ñopo 2008), lending support to the robustness of the baseline FFL results.

\section{Conclusions}

In conclusion, between 2004 and 2011, the gender wage gap in Georgia remained substantial but consistently contracted at the mean and across the wage distribution. The considerable size of the gender wage gap during 2004-2011 was due to the high degree of industrial segregation and the large proportion of women employed in the state sector. Hence, the patterns that explain the gender wage gap in Georgia are similar to those observed in other countries, albeit more pronounced. About $60 \%$ of the gap during this period remains unexplained, suggesting a contributing role of unobservable factors, such as job flexibility and employer discrimination.

Between 2004 and 2007, the contraction in the gender wage gap could be largely attributed to the wage growth in the predominantly state-run industries that employ high-skill white-collar workers, most of whom are women. The expansion of these industries and of construction and transport contributed to the change in the shape of the gender wage gap distribution from upward to downward sloping. This happened because the growth in state sector wages lifted women's wages at the top of the distribution and the expansion of construction and transport raised men's wages at the bottom of the distribution. The greater increase in the working hours 
of women at the top and men at the bottom of the distribution also played a role in changing the shape of the gender wage gap.

On the other hand, between 2007 and 2011, the gender wage gap contracted because the recession hit the male-dominated construction and manufacturing industries especially hard. Additionally, women may have entered the labor force in response to this shock in a manifestation of the added-worker effect, consistent with evidence from other countries of the transition region (Khitarishvili 2013). Both factors played a role in contributing to the inverted-U shape of the gender wage gap distribution in 2011.

Our findings underscore the importance of recognizing and accounting for the gender-specific nature in which reforms and economic shocks influence the economy. In particular, state sector reforms in Georgia played an important and swift role in reducing the gender wage gap, even though that was not their primary intention. Moreover, the impact of the recession was far from gender neutral, and the recession contributed to the reduction of the gender wage gap in Georgia. The analysis also reveals that the contraction in the gender wage gap in Georgia was not associated with considerable shifts in the economic composition of the private sector. Indeed, unlike in other countries in which the expansion of the service sector was instrumental in lowering the gender wage gap (Ngai and Petrongolo 2013), in Georgia, the private component of the service sector appears to have played a rather limited role in lifting women's relative position and in reducing the gender wage gap.

Importantly, the results emphasize the need to investigate and address the role of entrenched institutional, social, and cultural factors, manifested in large unexplained components of the gap. In this dual context, the reduction in the magnitude of the glass ceiling effect that appears to have taken place between 2004 and 2007, for example, can be seen solely as a by product of the wage-growth changes in the state sector rather than a manifestation of the fundamental shifts in advancement opportunities accessible to women in all sectors of the economy.

In addition to the factors analyzed in this paper, other elements may have played a role in influencing the magnitude of the gender wage gap and its evolution between 2004 and 2011. For example, previous work suggests that accounting for the selection into employment resulted in a wider adjusted gender wage gap in Georgia (Khitarishvili 2009). Future studies should focus on assessing the extent to which the sample selection bias varies across the wage distribution and, importantly, over a business cycle. For instance, if the recession-induced female added-worker effect is driven by women with poor labor market characteristics, the bias is likely to be lower during recessions. This issue warrants further investigation and can advance our understanding of the factors that underlie movements in the gender wage gap across the wage distribution and over business cycles.

\section{Endnotes}

${ }^{1} \mathrm{~A}$ sizable literature documents the evolution of the mean gender wage gap in transition countries, e.g., Brainerd (1998), Newell and Reilly (1996), Arabsheibani and Lau (1999), Glinskaya and Mroz (2000), Gerry et al. (2004), Giddings (2002), Kazakova (2007), Johnes and Tanaka (2008), and Anderson and Pomfret (2003). 
${ }^{2}$ In addition, Atencio and Posadas (2015) analyze the distribution of the gender wage gap in Russia in 2011 but do not assess its evolution over time.

${ }^{3}$ Additionally, we conduct the analysis for each of the intermediate years. Our findings indicate that the changes between 2004 and 2007 and 2007 and 2011 were gradual, lending support to the choice of these years and the robustness of our results. Detailed results for the intermediate years are available upon request.

${ }^{4}$ The standard errors reported in the analysis are bootstrapped with 200 replications and are clustered by households. The results are robust to a higher number of replications. Clustering by households takes into account the survey design, in which several individuals from the same household are surveyed. Moreover, it partially addresses the panel dimension of the data because the same household may appear several times in the dataset.

${ }^{5}$ Also, the quality of the earnings data is likely to be higher for wage workers than for self-employed individuals (Benedek and Lelkes 2011; Johansson 2005), although Torosyan and Filer (2014) find that in Georgia the degree of underreporting is in fact similar between these groups.

${ }^{6}$ Skill corresponds to four occupational categories based on the ISCO-88 single-digit occupation coding: 1-3 = high-skilled white-collar (such as teachers, physicians, engineers); 4-5 = low-skilled white-collar (such as office clerks, sales, and customer service personnel); 6-7 = high-skilled blue-collar (such as machine operators and skilled agricultural workers); and 8-9=low-skilled blue-collar (such as drivers, movers).

${ }^{7}$ The year 2007 was chosen as the peak year in the analysis because the impact of the crisis became visible in the data by 2008 . We note in the text, however, that some sectors of the economy continued growing until 2008 and 2009. The analysis of the intermediate years, the results of which are available upon request, also supports the choice of 2007 as the break point.

${ }^{8}$ Log point gap is defined as $\ln \left(W_{m} / W_{w}\right)$.

${ }^{9}$ Figure 3 in the Appendix plots the distribution of the gender wage gap for each year between 2004 and 2011. It can be seen that the changes in the shape of the distribution were gradual between 2004 and 2007 and then between 2007 and 2011, with 2007 as a turning point.

${ }^{10}$ The underlying assumption is that men's wages are the nondiscriminatory wages although, in principle, one could also evaluate the counterfactual that corresponds to men's earnings if they had the same returns as women. In that case, women's returns are viewed as the nondiscriminatory returns. Another alternative is to use an average of the two wages.

${ }^{11} \mathrm{We}$ report only the decomposition results. The estimation results of the RIF regressions are available upon request.

${ }^{12}$ We report the results for 2004, 2007, and 2011. The results for the intermediate years are available upon request. They reveal that the changes between 2004 and 2007 and between 2007 and 2011 were gradual, lending support to the robustness of the reported results.

${ }^{13}$ I thank the anonymous reviewer for making this point.

${ }^{14}$ The decomposition results for the intermediate years are available upon request.

${ }^{15}$ The full set of matching variables includes dummy variables for age, education, marriage, skill level, state sector, industry, urban residence, Tbilisi, work hours, and ethnicity.

${ }^{16}$ We note that the results for 2004, 2007, and 2011 must be interpreted in light of their relatively small sample size. 


\section{Appendix}

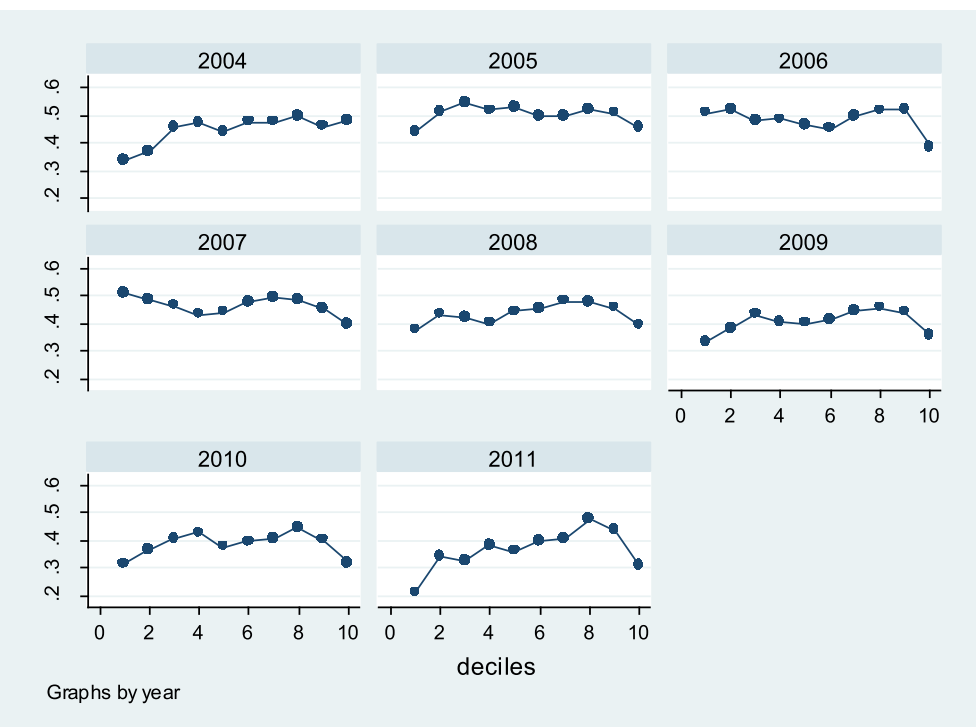

Fig. 3 Raw gender wage gap across the wage distribution, for all years. Source: GHBS data

\section{Acknowledgements}

This study was financially supported by the World Bank's Gender Assessment Program in the South Caucasus. The author thanks the anonymous reviewer, the editor, and participants of seminars at the World Bank, Harvard University's Davis Center for Russian and Eurasian Studies, and Bard College for their useful comments. The usual disclaimer applies.

Responsible editor: Hartmut F. Lehmann

\section{Competing interests}

The IZA Journal of Labor \& Development is committed to the IZA Guiding Principles of Research Integrity. The author declares that she has observed these principles.

Received: 25 April 2016 Accepted: 15 September 2016

Published online: 27 October 2016

\section{References}

Anderson KH, Pomfret RWT (2003) Consequences of creating a market economy: evidence from household surveys in Central Asia. Edward Elgar Publishing, Cheltenham

Arabsheibani R, Lau L (1999) 'Mind the gap': an analysis of gender wage differentials in Russia. Labour 13:761-774

Atencio A, Posadas J (2015) Gender gap in pay in the Russian Federation: twenty years later, still a concern. World Bank Policy Research Working Paper \#WPS 7407. Washington, DC

Benedek D, Lelkes O (2011) The distributional implications of income underreporting in Hungary. Fisc Stud 32(4):539-560 Blinder A (1973) Wage discrimination: reduced form and structural estimates. J Hum Resources 8:436-455

Brainerd E (1998) Winners and losers in Russia's economic transition. The American Econ Rev 88:1094-1116

Chi W, Li B (2008) Glass ceiling or sticky floor? Examining the gender earnings differential across the earning distribution in urban China, 1987-2004. J of Comp Econ 36:243-263

Christofides LN, Polycarpou A, Vrachimis K (2013) Gender wage gaps, 'sticky floors' and 'glass ceilings' in Europe. Labour Econ 21:86-102

Deaton AS (1997) The analysis of household surveys: microeconometric analysis for development policy. Johns Hopkins University Press, Baltimore

Dechter EK (2014) Maternity leave, effort allocation, and postmotherhood earnings. J of Hum Cap 8(2):97-125

Firpo S, Fortin NM, Lemieux T (2007) Decomposing wage distributions using influence function projections. Economics Working paper, University of British Columbia

Firpo S, Fortin NM, Lemieux T (2009) Unconditional quantile regressions. Économ 77:953-973

Ganguli I, Terrell K (2005) Wage ceilings and floors: the gender wage gap in Ukraine's transition. Institute for the Study of Labor (IZA) Working Paper \#1776, Bonn

Garcia-Mainar I, Montuenga-Gomez V (2005) Education returns of wage earners and self-employed workers: Portugal vs. Spain. Econ Education Rev 24:161-170

Gerry CJ, Kim B, Li CA (2004) The gender wage gap and wage arrears in Russia: evidence from the RLMS. J Popul Econ $17: 267-288$ 
Giddings L (2002) Changes in gender earnings differentials in Bulgaria's transition to a mixed-market economy. East Econ J 28:481-497

Glinskaya E, Mroz TA (2000) The gender gap in wages in Russia from 1992 to 1995. J of Popul Econ 13:353-386 Jashi C (2005) Gender economic issues: the case of Georgia. UNDP/SIDA, Tbilisi

Johansson E (2005) An estimate of self-employment income underreporting in Finland. Nordic J Political Econ 31:99109

Johnes G, Tanaka Y (2008) Changes in gender wage discrimination in the 1990s: a tale of three very different economies. Japan and the World Econ 20:97-113

Juhn C, Murphy K, Pierce B (1993) Wage inequality and the rise in returns to skill. J Political Econ 101:410-442

Kazakova E (2007) Wages in a growing Russia: when is a 10 per cent rise in the gender wage gap good news? Econ Trans 15:365-392

Kecmanovic M, Barrett G (2011) The gender wage gap during Serbia's transition. Comp Econ Stud 53:695-720 Khitarishvili T (2009) Explaining the gender wage gap in Georgia. Levy Economics Institute Working Paper \#577, Annandale-on-Hudson, NY

Khitarishvili T (2013) The economic crisis of 2008 and the added worker effect in transition countries. In: Antonopoulos R (ed) Gender perspectives and gender impacts of the global economic crisis. Routledge, London and New York

Maani SA, Cruickshank AA (2010) What is the effect of housework on the market wage, and can it explain the gender wage gap? J of Econ Surv 24:402-427

Machado J, Mata J (2005) Counterfactual decomposition of changes in wage distributions using quantile regression. J Appl Économ 20:445-465

Newell A, Reilly B (1996) The gender wage gap in Russia: some empirical evidence. Labour Econ 3:337-356

Ngai LR, Petrongolo B (2013) Gender gaps and the rise of the service economy. Centre for Economic Performance Discussion Paper \# 1204, London

Ñopo H (2008) Matching as a tool to decompose wage gaps. The Rev of Econ and Stat 90:290-299

Oaxaca R (1973) Male-female wage differentials in urban labor markets. Int Econ Rev 14:693-709

Papava V (2012) Economic reforms in post-communist Georgia: twenty years after. Nova Science Publisher, Hauppauge

Pastore F, Verashchagina A (2011) When does transition increase the gender wage gap? An application to Belarus. Econ of Transit 19:333-369

Pham HT, Reilly B (2007) The gender pay gap in Vietnam, 1993-2002: a quantile regression approach. J Asian Econ 18: $775-808$

Pignatti N (2012) Gender wage gap dynamics in a changing Ukraine. IZA J of Labor and Dev 1(7):1

Pitts JD, Orozco-Aleman S, Rezek J (2014) The role of supervisors in the determination of wages and wage gaps. Applied Econ 46(29):3533

Schmid G (2010) Non-standard employment and labour force participation: a comparative view of the recent developments in Europe. IZA Discussion Paper \#5087, Bonn

Torosyan K, Filer K (2014) Tax reform in Georgia and the size of the shadow economy. Econ of Transit 22:179-210

Winder KL (2009) Flexible scheduling and the gender wage gap. The BE J of Econ Analysis \& Policy 9(1):1-27

World Bank (2012) Opportunities for men and women: emerging Europe and Central Asia. World Bank, Washington, DC Yemtsov R (2001) Labor markets, inequality and poverty in Georgia. IZA Discussion Paper \#251, Bonn

\section{Submit your manuscript to a SpringerOpen ${ }^{\circ}$ journal and benefit from:}

$\checkmark$ Convenient online submission

- Rigorous peer review

- Immediate publication on acceptance

- Open access: articles freely available online

- High visibility within the field

Retaining the copyright to your article 